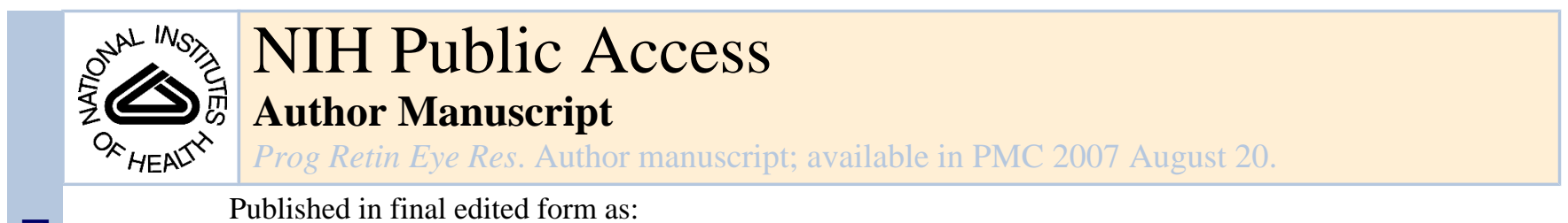

Published in final edited form as:

Prog Retin Eye Res. 2004 March ; 23(2): 229-249.

\title{
Genetic factors of age-related macular degeneration
}

\author{
Jingsheng Tuo, Christine M. Bojanowski, and Chi-Chao Chan ${ }^{\star}$ \\ Laboratory of Immunology, Immunopathology Section, National Eye Institute, National Institutes of \\ Health, Bldg. 10, Rm. 10N103, 10 Center Drive, Bethesda, MD 20892-1857, USA
}

\begin{abstract}
Age-related macular degeneration (AMD) is a leading cause of blindness in the United States and developed countries. Although the etiology and pathogenesis of AMD remain unknown, a complex interaction of genetic and environmental factors is thought to exist. The incidence and progression of all of the features of AMD are known to increase significantly with age. The tendency for familial aggregation and the findings of gene variation association studies implicate a significant genetic component in the development of AMD. This review summarizes in detail the AMD-related genes identified by studies on genetically engineered and spontaneously gene-mutated (naturally mutated) animals, AMD chromosomal loci identified by linkage studies, AMD-related genes identified through studies of monogenic degenerative retinal diseases, and AMD-related gene variation identified by association studies.
\end{abstract}

\section{Introduction}

Age-related macular degeneration (AMD) is a chronic and progressive degeneration of photoreceptors, the underlying retinal pigment epithelium (RPE), Bruch's membrane and possibly the choriocapillaries in the macula (Fine et al., 2000;Hageman et al., 2001;Lutty et al., 1999). The macula is a highly specific region, $6 \mathrm{~mm}$ in diameter, located in the central retina temporally to the optic disc. At the center of the macula lies the fovea, $0.35 \mathrm{~mm}$ in diameter, which contains a population of photoreceptor cells responsible for reading and color vision. Clinical and pathological features of AMD include alteration of Bruch's membrane and RPE cells, drusen formation, hypo- and/or hyperpigmentation, loss of photoreceptors, choroidal neovascularization, and subretinal fibrous and/or neovascular tissue in the macula. These alterations result in the loss of central visual acuity (Ambati et al., 2003a). Although laser photocoagulation targeting the choroidal feeding vessels, photodynamic therapy, surgical macular translocation, and antiangiogenesis agents are reported to reduce the risk of moderate to severe vision loss in some patients with the neovascular, or wet, form of the disease, there is no proven treatment of advanced AMD to date (Ciardella et al., 2002;Fujii et al., 2003;Lim, 2002;McBee et al., 2003; Rechtman et al., 2002).

AMD is the leading cause of visual impairment and blindness in the United States and the developed world among people 65 years and older (la Cour et al., 2002). AMD prevalence was observed in $9 \%$ of the population from ages 52-85 years old in the Framingham study and in $33 \%$ of autopsied eyes obtained after death from people older than 65 years (Kini et al., 1978; Kornzweig, 1965). Roughly 30\% of the human population 75 years or older has some degree of AMD. As the average life span of humans continues to increase, particularly in the developed countries, the incidence of AMD is expected to nearly double within the next 25 years (Smith et al., 2001).

*Corresponding author. Tel.: +1-301-496-0417; fax: +1-301-402-8664. E-mail address: chanc@ nei.nih.gov (C.-C. Chan). 
Currently, the etiology of AMD remains elusive. In addition to age, recognized risk factors include cigarette smoking and diet (Age-Related Eye Disease Study Research Group, 2000, 2001; Husain et al., 2002;Hyman and Neborsky, 2002;Seddon et al., 2001). RPE dysfunction mediated by reactive oxygen intermediates has also been suggested as a possible cause of AMD (Beatty et al., 2000). Due to the importance of antioxidants in scavenging free radicals, many investigators have speculated that dietary antioxidants and mineral cofactors confer protection against AMD (Frank, 1998;Frank et al., 1999). Oxidative stress may promote neovascularization via deposition of extracellular matrix along Bruch's membrane and increased levels of the angiogenic factors in RPE cells (Mousa et al., 1999). The results of the age-related eye disease study (AREDS, 2001) suggest a moderate benefit of antioxidant, vitamin and mineral supplementation in curbing the progression of neovascular AMD.

Different opinions are held concerning the association between AMD and hypertension (Delcourt et al., 2001;Hyman and Neborsky, 2002;Snow and Seddon, 1999). Among all identified potential environmental factors, only age, diet and smoking are agreed upon by all to increase the risk of AMD.

The pathogenesis responsible for AMD involves environmental factors and varying susceptibilities to these external factors based upon different genetic backgrounds (Guymer, 2001). Ethnicity, for example, is a component of genetic background. AMD is more prevalent in people with less pigmentation, although little difference in the occurrences of smaller-size drusen in individuals with light and dark skin has been reported (Age-Related Eye Disease Study Research Group, 2000,2001;Friedman et al., 1999). A possible explanation for this observed trend suggests an enhanced protective role for the melanin in RPE cells and choroidal melanocytes. There has been compelling documented evidence that heredity plays a role in AMD (Yoshida et al., 2000). The tendency for familial aggregation in AMD cases further points to a genetic background for the disease. Approximately 20\% of AMD patients have a positive family history (de Jong et al., 1997;Klaver et al., 1998b;Meyers et al., 1995). Furthermore, there is higher prevalence of AMD among monozygotic twins as compared to their spouses and first-degree relatives (Gottfredsdottir et al., 1999;Klaver et al., 1998b). Recently, the potential role of genetic variation in AMD development has gained attention. Gene variation has been reported in association with various other human age-related diseases such as cancer and the cardiovascular diseases (Brennan, 2002;Gulcher et al., 2001;Halushka et al., 1999). A few small studies have also demonstrated the association between AMD and various gene polymorphisms (Husain et al., 2002;Schmidt et al., 2000). This review will discuss in detail the currently known genetic risk factors associated with AMD.

\section{AMD-related genes identified by genetically engineered or spontaneously gene-mutated (naturally mutated) animals}

Characterization of animals with retinal degeneration due to genetic engineering or spontaneous gene mutations is an important approach for obtaining information on critical retinal degeneration pathways. Knowledge of the genetic homologies and similar phenotypes between mice, rats, and humans could lead to the identification of relevant human genes.

\subsection{Genetically engineered animal models}

AMD-like clinical and pathological features have been induced in genetically modified animals. A series of retinal degeneration animal models have been established based on the known retinal degeneration-related genes identified through studying monogenetic retinal diseases and gene variation association studies as discussed below. Various clinical signs of retinal degeneration are mimicked in $A B C A 4$ (a photoreceptor-specific ATP-binding cassette transport gene, alternatively named $A B C R$ ) knockout mice (Mata et al., 2001;Weng et al., 1999); Apolipoprotein $E$ ( $A p o E$, a ligand for the low-density lipoprotein (LDL) receptor 
family) knockout mice (Dithmar et al., 2000); Apo(*)E3-Leiden mice that carry a dysfunctional form of human ApoE- $\varepsilon 3$ discovered in a family from the Dutch town Leiden (Kliffen et al., 2000); and knock-in mice that carry a disease-related Ser156Cys mutation in the tissue inhibitor of metalloproteinases-3 (TIMP3) gene (Weber et al., 2002).

Through genetically engineered animal studies alone, several retinal degeneration-related genes have been identified. The phenotype of RPE65 knockout mice indicates a role for rhodopsin in retinal degeneration. The RPE65 gene has been refined to human chromosome $1 \mathrm{p} 1$ and mouse chromosome 3. RPE65 is an RPE-specific 65-kDa protein localized to the microsomal membranes of vertebrate RPE. RPE65 functions in the isomerization of 11trans to 11- cis retinol and partly in RPE rhodopsin regeneration (Hamel et al., 1993,1994). The RPE65 knockout in mice confers a sensitivity to light damage which mimics certain aspects of retinal degeneration (Gouras et al., 2002;Katz and Redmond, 2001;Rohrer et al., 2003; Wenzel et al., 2003). Spontaneous progressive photoreceptor degeneration was also found in RPE65 knockout mice (Gouras et al., 2002). However, RPE65 is unlikely relevant to AMD.

Another animal model for retinal degeneration is based on the $\mathrm{mcd} / \mathrm{mcd}$ transgenic mouse (Rakoczy et al., 2002). Cathepsin D (CatD) is an important and widely expressed aspartic protease responsible for the digestion of phagocytosed opsin photoreceptor outer segments by the RPE. RPE cells have been shown to express high levels of CatD. Changes in cathepsin's lyposomal activity have been associated with many diseases. CatD is first produced in a preprocathepsin form and then subjected to a series of cleavage and activation steps. The mcd/ mcd transgenic mouse expresses a mutated form of cathepsin D (CatD) that mimics human CatD lacking Glu44p and Gly1 cleavage sites (Rakoczy et al., 2002). Circulating levels of CatD are not affected by these mutations and remain high. Improper cleavage, however, does render circulating CatD enzymatically inactive. These inactive forms are thought to impair rod outer-segment degradation, which eventually leads to the development and accumulation of hyalinized drusen (Rakoczy et al., 1996,1999). In old age, the $\mathrm{mcd} / \mathrm{mcd}$ mice exhibit most features of human AMD such as RPE pigmentary changes, attenuation, hyper- and hypoplasia, proliferation and atrophy of RPE cells, accumulation of basal laminar and linear deposits, and decreased retinal sensitivity. Under the light microscope, geographic atrophy appears in the advanced stage (Rakoczy et al., 1996,2002).

Mouse knockouts of the $\mathrm{C}-\mathrm{C}$ chemokine $\mathrm{Ccl} 2$ (MCP-1) or its cognate receptor-2 (Ccr2) spontaneously develop various cardinal features of AMD in their senescence stage. These observations suggest that normal $\mathrm{Cc} 2 / \mathrm{Ccr} 2$ function confers some degree of protection against AMD (Ambati et al., 2003b). Ccl2 and Ccr2 are involved in monocyte and macrophage chemoattraction. $\mathrm{Ccl} 2$ and $\mathrm{Ccr} 2$ also possibly play roles in degrading the deposits accumulated over age in Bruch's membrane. Different from other AMD animal models, in which only the dry type or wet type of AMD is mimicked by either drusen formation or neovascularization, respectively; $\mathrm{Ccl} 2$ and $\mathrm{Ccr} 2$ knockouts develop both dry and wet AMD types with the wet type as the advanced stage. The pathological changes in these aged mice include photoreceptor atrophy, choroidal neovascularization, accumulation of lipofuscin in the RPE, and the formation of drusen beneath the RPE. As in humans, complement and IgG deposition in the choroid accompanies senescence in these animal models. RPE or choroidal endothelial production of $\mathrm{Ccl} 2$ induced by complement $\mathrm{C} 5 \mathrm{a}$ and $\mathrm{IgG}$ may mediate choroidal macrophage infiltration in the aged wild-type choroid. Therefore, impaired macrophage recruitment possibly results in $\mathrm{C} 5 \mathrm{a}$ and $\mathrm{IgG}$ accumulation, which in turn induces vascular endothelial growth factor (VEGF) production by the RPE. VEGF is a possible mediator of choroidal neovascularization development. The $\mathrm{Ccl} 2 / \mathrm{Ccr} 3$ model implicates macrophage dysfunction in the pathogenesis of AMD and may be a useful platform in validating therapies (Ambati et al., 2003b).

Prog Retin Eye Res. Author manuscript; available in PMC 2007 August 20. 


\subsection{Spontaneously gene-mutated (naturally mutated) animal models}

Mouse strains with spontaneous retinal degenerations have been used for many years to identify genes that cause retinal degeneration. Many of these animal models come from screening genetically independent mouse strains and stocks using indirect ophthalmoscopy and electroretinography (Chang et al., 1993,1994;Heckenlively et al., 1989). These mice develop photoreceptor dysfunction leading to the death of both rod and cone photoreceptors. The mechanism behind photoreceptor cell death, which mimics the dry form of AMD, is thought to be the process of apoptosis (Chader, 2002).

The retinal degeneration $6(r d 6)$ mouse, from the $\mathrm{C} 3 \mathrm{HfB} / \mathrm{GaCas} 1 \mathrm{~b}$ strain, is one animal model identified by such genomic screenings (Kameya et al., 2002). The inheritance pattern of $r d 6$ is autosomal recessive. Fundus examination of $r d 6$ homozygous mice shows distribution of discrete dots across the retina. Mice homozygous for the $r d 6$ mutation exhibit retinal dysfunction and a slow progressive photoreceptor degeneration (Hawes et al., 2000). Mfrp within the $r d 6$ region was identified as responsible for the photoreceptor degeneration in these $r d 6$ mice by positional cloning. Other animal models in the rd series have been intensively reviewed byChang et al. (2002).

Bst/+ is a spontaneous, autosomal, semi-dominant mouse mutation in the Belly spot and tail (Bst) gene mapped to mouse chromosome 16, 1.9 $\pm 1.1 \mathrm{cM}$ from D16Mit168 (Rice et al., 1997). In early onset, the main retinal features of Bst/+ mice are summarized as defective development. In mice older than 7 months of age, choroidal neovascularization is seen to extend into the outer portion of the sensory retina. This neovascularization pattern is similar to that observed in the advanced stage of human wet-type AMD. Cloning of the Bst gene and the identification of the homologous human gene may be useful in uncovering this gene's role in choroidal neovascularization (Smith et al., 2000).

The RD locus was first identified by retinal degeneration linkage studies carried out in mice (Sidman and Green, 1965). The RDS gene was originally identified in a strain of mice with a form of photoreceptor degeneration termed "retinal degeneration, slow" (rds) (Demant et al., 1979; van Nie et al., 1978). The rds mouse, which, in genotype, is homozygous for a null mutation in peripherin / RDS , completely fails to develop photoreceptor discs and outer segments, and exhibits down-regulation of rod opsin expression and apoptotic loss of photoreceptor cells (Kohl et al., 1998). Peripherin/RDS mutations in codons 169, 172, and 195 have been identified in autosomal dominant macular dystrophy (Downes et al., 1999;Ekstrom et al., 1998;Lith-Verhoeven et al., 2003b;Nakazawa et al., 1995;Payne et al., 1998;Piguet et al., 1996;Wells et al., 1993; Yanagihashi et al., 2003). Recently, Khani et al. (2003)reported that a $R D S$ mutation in codon 141 is associated with an unusual AMD-like late-onset maculopathy.

\section{AMD chromosomal loci identified by linkage studies}

A genome-wide scan of extended families with AMD is one of the approaches taken to locate candidate AMD loci. The total relative likelihood for a possible linkage relationship among selected loci is expressed by a lod, an acronym for "logarithm of odds", score. A lod score of 3 is generally considered to be an acceptable criterion for demonstration of loci linkage. A threshold of lod $=2$ is often used as a criterion for suggestive linkage (Majewski et al., 2003). The Hlod parameter, which takes into account both lod score likelihood estimations and heterogeneity, was a necessary addition to linkage studies of complex diseases such as AMD. Lander and Kruglyak (1995)have recommended that a lod score of 3.3 be considered a reasonable criterion for linkage in studies using lod score analysis in humans. Slightly higher lod scores, for example, 3.6-3.8, they suggest, might be appropriate for allele sharing methods. Majewski et al. (2003)recently reported multiple loci in linkage by a genome-wide scan in 70

Prog Retin Eye Res. Author manuscript; available in PMC 2007 August 20. 
families, ranging from small nuclear families to extended multigenerational pedigrees. This study included a total of 344 AMD cases and 217 unaffected members. Findings in this study confirmed the linkage previously identified at chromosome 1q25-31 in a single large family (Majewski et al., 2003). This locus was also previously reported by other investigators (Klein et al., 1998;Schick et al., 2003;Weeks et al., 2001). However, the locus was defined at D1S518 byMajewski et al. (2003), between markers D1S466 and D1S413 byKlein et al. (1998), and between markers D1S1660 and D1S1647 bySchick et al. (2003).

In the same study, Majewski et al. (2003)also achieved a Hlod score of 3.06 with marker D10S123 on chromosome 10q26. This locus has also been reported elsewhere (Weeks et al., 2001;Kenealy et al., 2004). Through the use of correlation analysis, a statistically significant correlation was established between lod scores at 10q26 and 3p13, another AMD locus identified in this study. Loci at 4q32 (D4S2368) and 3p13 (D3S1304/D3S4545) have been linked to the predominantly dry-AMD phenotype in a subgroup of families with Hlod scores of 2.66 and 2.19, respectively (Majewski et al., 2003). D9S934 at chromosome 9q33 has been linked to AMD with a lod score of 2.01 in 21 families (Majewski et al., 2003).

In addition to the loci at chromosome positions 1q31 and 10q26, a study of 860 affected individuals from 391 families (452 sib pairs) reported linkage to markers on chromosome 17q25 (Weeks et al., 2001). Using their most stringent diagnostic model, Weeks et al. (2001) found the 17q25 Hlod score at D17S928 was 3.16. This locus has also been reported elsewhere (Schick et al., 2003). Positive lod scores of 3.59 and 3.1 were reported for D6S1644 and D6S249, respectively, at chromosome 6q14 (Kniazeva et al., 2000). Seddon et al. (2003) reported the linkage of AMD to D22S1045 at chromosome 22q12, and D2S1391 and D2S1384 at chromosome 2q31-32. Table 1summarizes the chromosomal loci with lod scores greater than 2 identified in linkage studies with AMD.

Most recently, Iyengar et al. (2004)reported a novel major AMD locus on chromosome 15q21 (GATA50C03/D15S659) with $P=2 \times 10^{-7}$ by dissecting genome-wide scan data of extended families and using a quantitative trait linkage approach. In this study, AMD was graded on a 16-level quantitative scale for severity based on drusen size, type, and area; pigmentary abnormalities; geographic atrophy; and signs of exudative macular degeneration. This quantitative scale thus provides increased power in detecting linkage signals as compared to the study carried out by Schick et al. (2003)using the assignment of binary affection status based on clinical criteria or threshold value from the same data pool.

AMD genes can also be identified following further paring down and refining of linked AMD loci. Schultz et al. (2003b)recently reported an AMD gene, hemicentin-1, after further mapping of the ARMD1 region in 1q25-31. This region was previously discovered in a genome-wide scan (Klein et al., 1998). There are roughly 50 genes within the ARMD1 region. Mutation screening targets were prioritized based on their expression in the retina, their similarity to genes known to cause retinal disorders, and whether or not they encode extracellular matrix proteins or proteins potentially related to drusen formation. A total of 20 genes in the refined ARMDI region were screened. Through these screens, an A16263G variation in exon 104 of hemicentin-1 was found. This site is in conjunction with the disease haplotype although it was not found in conjunction with any of the other 17 haplotypes reported across the ARMDI region in the pedigree studied (Schultz et al., 2003b). None of the 11 family members who lacked the disease haplotype carried the $\mathrm{A} 16263 \mathrm{G}$ variation, an observation which further strengthens the significance of this finding.

The A16263G variation causes a non-synonymous substitution of arginine for glutamine at amino acid position 5345 (Gln5345Arg). Alignment of the amino acid sequence of a portion of hemicentin- 1 exon 104 in humans shows that Gln5345 is conserved in seven mammalian 
species as well as in chickens. Little is known concerning the function of hemicentin-1. The protein sequence of hemicentin-1 is similar to that of hemicentin (Vogel and Hedgecock, 2001), a conserved extracellular matrix protein belonging to the immunoglobulin superfamily in Caenorhabditis elegans . Hemicentin functions as an organizer of epithelial and other cell attachments into oriented line-shaped junctions. Mutations in him-4, the gene which codes hemicentin, cause tissue fragility, defective cell migration and chromosome instability in $C$. elegans. The predicted protein sequence of hemicentin -1 resembles EFEMP1 (EFGcontaining fibulin-like extracellular matrix protein-1), a causative gene in autosomal dominant radial drusen development (see below). Both hemicentin -1 and EFEMP1 encode extracellular matrix proteins that contain a series of calcium-binding epidermal growth factor-like domains followed by an unusual carboxy terminal EGF-like domain with eight cysteines.

Iyengar et al (2004)followed linkage analysis of the extended families-based AMD cases with testing the sequence variation of hemicentin-1 in 1q31 linked families. Instead of finding any variation in exon 104 of hemicentin-1, four hemicentin-1 SNPs (see Section 5), rs 1475113 in intron 4, rs743137 in intron 36, hCV625089 in intron 86, and rs680638 in intron 105, were found to possibly be AMD related. Inclusion of these SNPs as markers in the linkage model has contributed significantly to the overall evidence for linkage at 1q31.

\section{AMD-related genes identified by studies of monogenic degenerative retinal diseases}

There are many limitations in causative gene mapping through linkage studies in late-onset diseases such as AMD. First, many individuals in the affected families are young and have not yet reached the age of disease onset (which, in the case of AMD, is over the age of 50 years); second, it is likely that many older family members have passed away making informative individuals from multiple generations rarely available; and third, the heterogeneity of AMD requires the estimation of multiple genetic risks as this disease is believed to result from mutations in two or more different and unrelated genes rather than from single gene disruption. Furthermore, the variable presentation of AMD leads to difficulty and imprecision in the classification of the affected individuals (Seddon et al., 2003). For these reasons, the study of other hereditary monogenic macular and retinal dystrophies that share clinical and pathological similarities with AMD may offer some insightful clues in the search to identify AMD-related genes.

\subsection{Stargardt macular dystrophy (STGD)}

Various studies have reported $A B C A 4$ in $1 \mathrm{p} 21$ as a causative gene of Stargardt macular dystrophy (STGD), a blinding autosomal recessive retinal dystrophic disease that affects children and teenagers (Kaplan et al., 1993). STGD is characterized by delayed dark adaptation and accelerated deposition of lipofuscin in the RPE (Allik-mets et al., 1997b;Birnbach et al., 1994). STGD is of high heterogeneity and shares many features with AMD. The ABCA4 gene encodes the rim protein $(\mathrm{RmP})$, an integral membrane glycoprotein localized to the rims of photoreceptor outer-segment discs (Azarian and Travis, 1997). RmP belongs to the ABC transporter superfamily and possibly functions as a flippase for $N$-retinylidenephosphatidylethanolamine, the normally occurring Schiff-base conjugate of phosphatidylethanolamine with all- trans -RAL (Mata et al., 2001). Deposition of the lipofuscin fluorophore $N$-retinylidene- $N$-retinylethanolamine (A2E) is seen in the STGD RPE layer (Weng et al., 1999). Accumulation of lipofuscin in RPE cells is observed in several forms of macular degeneration including AMD (Kliffen et al., 1997;Weng et al., 1999). Slow accumulation of lipofuscin is also seen during normal aging (Kennedy et al., 1995). RmP may prevent A2E deposition in RPE cells by eliminating A2E precursors from the photoreceptors. The association studies on sequence variants of $A B C A 4$ and AMD are discussed below. 
PROMLI has been identified as another causative gene for STGD (Maw et al., 2000). The gene PROML1 in 4p15 encodes human prominin (mouse)-like 1 (previously known as AC133 antigen), which belongs to the prominin family of five-transmembrane domain proteins. PROMLI is expressed in retinoblastoma cell lines and adult retina. The product of the mouse orthologue (prom) is concentrated in membrane evaginations at the base of the rod photoreceptor outer segments (Maw et al., 2000). Screening of a STGD4 pedigree revealed that affected individuals were homozygous for a nucleotide 1878 deletion in PROML1. This alteration is predicted to result in a frameshift at codon 614 that causes the premature termination of translation. Functional studies in transfected $\mathrm{CHO}$ cells have demonstrated that the truncated prominin protein fails to reach the cell surface, suggesting that the loss of prominin may lead to retinal degeneration via the impaired generation of evaginations or conversion to outer-segment disks (Maw et al., 2000).

\subsection{Sorsby fundus dystrophy (SFD)}

Sorsby fundus dystrophy (SFD) is an autosomal dominant disease clinically characterized by choroidal neovascularization and irregularities in the extracellular matrix of Bruch's membrane. SFD leads to an onset of night blindness in the third decade of life and a loss of central vision from macular atrophy by the fifth (Gregory-Evans, 2000;Weber et al., 1994a). The SFD locus was mapped to 22q13-qter, containing the gene for TIMP3. TIMP3 is known to play a pivotal role in the regulation of the matrix metalloproteinases, such as the collagenases and gelatinases. TIMP 3 thereby determines the extent of matrix degradation during normal tissue remodeling and regulates the homeostasis of the extracellular matrix (Weber et al., 1994a).

Point mutations in TIMP3 have been reported in affected members of two SFD pedigrees (Weber et al., 1994a). These mutations are predicted to disrupt the tertiary structure and consequently the functional properties of the mature protein. Mutations in TIMP3, including Ser181Cys (Carrero-Valenzuela et al., 1996;Weber et al., 1994a), Ser156Cys (Felbor et al., 1996; Soboleva et al., 2003), and Tyr172Cys (Jacobson et al., 2002), occur primarily in the Cterminal region of exon 5. The majority of the reported mutations in TIMP3 lead to a replacement of reference residue by cysteine residues. This substitution results in aberrant disulfide bond formation and an abnormal tertiary protein structure. These changes most likely alter TIMP3 -mediated extracellular matrix turnover thereby leading to the thickening of Bruch's membrane and the widespread accumulation of abnormal material beneath the RPE observed histologically (Capon et al., 1989; Chong et al., 2000).

The TIMP3 protein plays an important role in the regulation of choroidal neovascularization, a prominent feature in SFD as well as in the advanced stages of AMD (Anand-Apte et al., 1997). In vitro and in vivo vascular endothelial migration assays indicate that TIMP-3 inhibits chemotaxis of vascular endothelial cells toward VEGF and basic fibroblast growth factor (bFGF). In vitro, collagen gel invasion and capillary morphogenesis is inhibited. In vivo, bFGFinduced angiogenesis is reduced in the chorioallantoic membrane assays. Thus, TIMP3 has the potential to inhibit angiogenesis, most likely by blocking VEGF-2 receptors (Anand-Apte et al., 1997). In addition, Majid et al. (2002)have demonstrated that mutant TIMP3 can induce apoptosis of RPE cells. This finding suggests that apoptosis may be the final pathway for cell death in SFD.

\subsection{Best disease}

$V M D 2$ (alternatively referred to as the Bestrophin gene) has been identified as the causal gene of dominant juvenile onset vitelliform macular dystrophy, commonly known as Best disease. Best disease affects the central retina and is characterized clinically by the classical abnormal electrooculogram and the presence of round or oval yellow subretinal macular deposits. The

Prog Retin Eye Res. Author manuscript; available in PMC 2007 August 20. 
yellow material gradually reabsorbs over time, leaving an area of RPE atrophy and often subretinal fibrosis (Kramer et al., 2003; Michaelides et al., 2003;Petrukhin et al., 1998;Weber et al., 1994b). Occasionally, at the time of disintegration, there may be hemorrhage into the retina. Histopathology of autopsied eyes from a Best disease patient showed accumulation of lipofuscin throughout the RPE, similar to AMD (Frangieh et al., 1982). This disease exhibits extremely variable expressivity.

Most affected individuals carry mutations in the VMD2 gene (Kramer et al., 2003). The $V M D 2$ gene, containing 11 exons spanning $14.1 \mathrm{~kb}$ of genomic DNA, has been localized to 11q13.2-13.3 (Weber et al., 1994b). The gene encodes a 585-amino-acid protein known as bestrophin, which is selectively expressed in the RPE of the eye (Marquardt et al., 1998; Petrukhin et al., 1998). Bestrophin has sequence homology with the RFP protein family. These proteins have a conserved sequence of 350-400 amino acids and are found in organisms as diverse as the nematode, the fruit fly, and the mouse. The function of this family of proteins is currently unknown although bestrophin has been characterized as a possible chloride channel (Marquardt et al., 1998;Petrukhin et al., 1998). Analysis of 259 patients with AMD has shown no significant role of bestrophin mutation in AMD (Allikmets et al., 1999). This is confirmed in another independent study of 85 non-familial AMD patients (Akimoto et al., 2001).

\subsection{Malattia leventinese and Doyne honeycomb retinal dystrophy}

The disruption of EFEMP1 at 2p16-21 has been linked with Malattia leventinese, a dominant macular dystrophy, and Doyne honeycomb retinal dystrophy. Both of these disorders are characterized by confluent drusen accumulation beneath the RPE, an early hallmark of AMD (Heon et al., 1996;Stone et al., 1999). EFEMP1 is expressed in the tissues closest to the site of drusen formation (RPE, retina, and choroid) and encodes a protein homologous to a family of extracellular matrix glycoproteins known as the fibulins (Tran et al., 1997). EFEMP1 was originally isolated as a cDNA sequence (formerly S1-5 and FBNL) that was over-expressed in human fibroblasts obtained from a patient with Werner syndrome, a genetic disease characterized by accelerated ageing (Lecka-Czernik et al., 1995). It has been reported that abnormal accumulation of EFEMP1 in the eyes may accelerate drusen formation and cellular degeneration (Marmor-stein et al., 2002). EFEMP1 is an extracellular matrix protein. The high likelihood of the interaction between extracellular matrix proteins, such as adhesion molecules, collagens, elastins, fibronectins, laminins, tenascins, hemicentins and vitronectins, suggests an entire group of genes as possible candidates for involvement in drusen formation (Stone et al., 1999).

\subsection{Pattern dystrophies}

Disruptions in the peripherin/RDS gene on chromosome 6p21 have been identified in patients with pattern dystrophies characterized by a bilateral accumulation of lipofuscin-like material at the level of the RPE (Nichols et al., 1993a,b). These disruptions include the missense mutations Gly167Asp, Pro210Arg, Pro216Ser, and Cys213Tyr, as well as the protein truncating mutations Gln331 stop, a 4-base pair (bp) deletion at codon 140, a 2-bp frameshift deletion at codon 290, a 2-bp frameshift deletion at codons 299/300, and a large deletion that removes exons 2 and 3 of the peripherin/RDS gene (Lith-Verhoeven et al., 2003a). The peripherin/RDS protein is a membrane-associated glycoprotein restricted to photoreceptor outer-segment discs in a complex with ROM1. This protein may function as an adhesion molecule involved in the stabilization and maintenance of a compact arrangement of outersegment discs (Travis et al., 1991). Peripherin has also been shown to interact with the GARP domain (glutamic acid- and proline-rich region) of the beta-subunit of rod cGMP-gated channels in a complex including the $\mathrm{Na} / \mathrm{Ca}-\mathrm{K}$ exchanger (Poetsch et al., 2001). This interaction may have a role in anchoring the channel-exchanger complex in the rod outer-segment plasma membrane. A recent study has shown no association of peripherin/RDS with Butterfly-shaped 
macular dystrophy, a type of pattern dystrophy, underscoring the genetic heterogeneity characteristic of these diseases (Lith-Verhoeven et al., 2003a).

\subsection{Late-onset retinal degeneration (L-ORD)}

CTRP5 has recently been reported as the causal gene of late-onset retinal degeneration (LORD), an autosomal dominant disorder with striking clinical and pathological similarity to AMD (Hayward et al., 2003). Clinically, L-ORD is characterized by onset in the fifth to sixth decade of life with night blindness as the main clinical feature. Pathological features include thick punctuate yellow-white deposit between the basal lamina of the RPE and Bruch's membrane, progression to severe central and peripheral degeneration, and choroidal neovascularization and chorioretinal atrophy (Kuntz et al., 1996;Milam et al., 2000). L-ORD is distinct from AMD only in its Mendelian inheritance pattern and the pathological tendency towards a more extensive distribution of sub-RPE deposit and atrophy.

A $10 \mathrm{cM}$ genome scan in an extended L-ORD family enabled Hayward et al. (2003)to identify linkage to a $15 \mathrm{cM}$ interval in 11q23.3, flanked by D11S4127 and D11S4151, with a maximum lod of 6.77. Candidate gene analysis discovered a mutation in the CTRP5 gene which codes a short-chain collagen. The mutation of a highly conserved serine to arginine (Ser163Arg) in the $\mathrm{gClq}$ domain was found in 7/14 L-ORD families and 0/1000 control individuals, suggesting that this mutation is a L-ORD-causing founder mutation. CTRP5 is secreted by the RPE and is a potential constituent of Bruch's membrane. This protein most likely functions in the facilitation of basal RPE adhesion to Bruch's membrane by forming an extracellular hexagonal lattice. The Ser163Arg mutation likely impairs this adhesion process, thereby leading to the build-up of extracellular deposit. Another possible consequence of this mutation may be the formation of an abnormally high molecular weight aggregate, which in turn may alter the higher-order structure and consequently the interactions of the molecule. The precise role of CTRP5 remains to be established; however, the presence of a common founder mutation in LORD suggests that this protein exerts an important influence on age-related build-up of extracellular deposits, as seen in both L-ORD and AMD (Apfelstedt-Sylla et al., 1995;Jacobson et al., 2001;Kuntz et al., 1996;Milam et al., 2000). These results further imply that impaired adhesion between RPE and Bruch's membrane may be one of the mechanisms for retinal deposit.

\section{AMD-related gene variation identified by single nucleotide polymorphism (SNP) association studies}

Recently, studies have begun to provide evidence that genetic sequence variations may play important roles in the pre-symptomatic stages of AMD as well as in the specific pathogenesis of the different phenotypes of AMD. There are several types of genetic polymorphisms encountered in the human genome such as repeat polymorphisms, insertions and deletions. However, the majority of the DNA sequence variation in the human genome is in the form of SNPs. SNPs can be defined as persistent substitutions in at least one population of a single base with a frequency of more than $1 \%$. SNP analysis has become an attractive tool in the exploration of the genetic component of complex diseases such as AMD because these polymorphisms are easily visualized and typed, highly abundant, and extremely stable. There are three principal investigative approaches taken when designing AMD-related SNP variation association studies: (1) to examine SNPs that have already been correlated with other agerelated diseases that share similar pathological features with AMD; (2) to investigate SNPs in genes that have been implicated by other studies on monogenetic retinal and macular degenerative diseases as being AMD-related as described above; and (3) to focus on SNPs in genes that play roles in the proposed pathways involved in AMD development and pathogenesis. 


\subsection{AMD-related SNPs in genes associated with monogenic macular and retinal degenerative diseases}

As mentioned above, the recent progress made in the study of hereditary monogenic macular and retinal dystrophies has offered some investigatory leads in the study of AMD genetics. The similarities that arise between the phenotypic expression in these early onset diseases and some of the later onset complex traits seen in AMD suggest a potential involvement of these candidate genes in AMD. Once candidate genes have been implicated as being AMD related, variation within these genes in the forms of SNPs can be studied.Table 2 summarizes the AMD SNP-related findings of association studies investigating the implications of other monogenic dystrophies studies in AMD genetic research.

Variation screening of ELOVLA, the gene identified as causal to STGD-like macular dystrophy, in AMD patients or additional families with dominant macular dystrophy phenotypes has not uncovered any other disease-associated variants (Ayyagari et al., 2001). ELOVL4 encodes an enzyme presumably involved in the elongation of very long chain fatty acids. A total of 11 sequence variants were detected in the entire ELOVLA gene in AMD patients and age-matched controls. Three SNPs were detected in the non-coding region of the gene and eight amino acid changing variants were revealed in the coding region. The most common variant encountered was the ELOVL4 M299V in exon 6 (Ayyagari et al., 2001). No statistically significant association was found between sequence variants in the ELOVLA gene and susceptibility to AMD with similar rare allelic frequencies in both AMD case and control populations (Ayyagari et al., 2001).

Data from several independent studies exclude the possibility of a major role for $V M D 2$, the causative gene in juvenile-onset Best disease, in the genetic predisposition to AMD. Three independent groups have screened for variant VMD2 genes in large numbers of AMD patients and matched control populations. No disease-associated alterations were detected in any of the 200 AMD patients involved in one study (Kramer et al., 2000). Furthermore, this study observed no association between the four common intragenic polymorphisms $(221 \mathrm{~T} \rightarrow \mathrm{C}$, IVS4-24C $\rightarrow$ T, IVS-del (TCC) $)_{3}$ and 1410A $\rightarrow$ G) and AMD (Kramer et al., 2000). Another study reported 40 possible VMD2 mutations in patients with Best disease, 29 of which are novel, and the majority of which are only observed in patients with the Best disease phenotype. SSCP analysis only detected VMD2 sequences variants in five out of the total 321 AMD patients (roughly 1.5\%) included in this particular study (Lotery et al., 2000). Although no variants were detected in the 192 controls, this frequency difference is not significant enough to assume an association with confidence. A study of 259 patients with AMD found that allelic frequencies of the common polymorphisms associated with VMD2 were almost identical in both the patient and control populations. However, two novel alterations, T216I and L567F, which were absent in the control population, were identified in three AMD patients with the sporadic dry form of AMD (Allikmets et al., 1999). Albeit intriguing, VMD2 analysis in AMD patients has provided a small number of sequence variants with uncertain significance. Although, it is widely agreed that the VMD2 gene variations studied thus far do not significantly contribute to AMD development, as the T216I and L567F alterations imply, bestrophin, the protein encoded by $V M D 2$, variants may still predispose an individual to AMD in rare cases (Allikmets et al., 1999).

Metalloproteinases are secreted enzymes involved in the degradation and renewal of the extracellular matrix. Therefore, TIMPs have been associated with the regulation of extracellular matrix turnover. It has been observed that TIMP-3 content in Bruch's membrane is greatly elevated (roughly twofold) in AMD eyes as compared to matched control eyes ( $p$ $<0.001$ ) (Kamei and Hollyfield, 1999). Overactive and accumulated TIMP-3 is believed to contribute to the thickening of Bruch's membrane and the associated atrophy of the RPE and photoreceptors seen grossly in AMD patients by inhibiting normal membrane turnover.

Prog Retin Eye Res. Author manuscript; available in PMC 2007 August 20. 
No sequence variants in the TIMP3 coding region have been detected in AMD patients. Besides one sequence variation found in one patient with AMD, no other disease-causing mutations have been detected in this gene (Felbor et al., 1997). Familial linkage studies have also failed to implicate TIMP3 in AMD (De La Paz et al., 1997). Although no association has been established between AMD and the TIMP3 gene variations, it may be possible that a variation within the genes that regulate TIMP3 translation causes the observed protein-level elevation.

As previously mentioned, a single base change within the EFEMPI gene has been correlated with Malattia leventnese and Doyne honeycomb retinal dystrophy. Variations within this gene result in a misfolded protein that is poorly secreted. Retarded secretion leads to aberrant accumulation and retention within cells. Defective protein aggregates are a common feature among many degenerative diseases. EFEMP1 has been shown to play an important role in drusen formation and cellular degradation. However, the Arg345Trp variant of the EFEMPI gene does not appear to be associated with cases of early onset drusen that fall outside of these two diseases, nor does this variation appear to play a major role in AMD (Guymer et al., 2002). Out of the 494 AMD patients included in one study, neither mutations nor any abnormalities were found after screening the entire EFEMP1 coding region (Stone et al., 1999). Involvement of the Arg345Trp variant has been found to be absent in sporadic cases of AMD (Stone et al., 1999). EFEMP1 also does not appear to be correlated with familial AMD (Guymer et al., 2002). SSCP analysis has determined that the variant is not evident in control populations, suggesting that this is a disease-causing allele mutation rather than a polymorphism (Guymer et al., 2002). Further studies are required in order to determine the role EFEMP1 plays in the etiology and pathology of AMD.

Human $G$ protein coupled receptor-75 (GPR75) is a two-exon gene that encodes a G-protein coupled receptor whose neuronal expression is restricted primarily to the retina and brain. GPR75 was originally studied during the hunt for the causal gene of Doyne honeycomb retinal dystrophy and Malattia leventnese prior to the establishment of EFEMPI's role in these disorders (Sauer et al., 2001). Genetic screening, however, revealed no association between sequence variations within this gene and the development and pathogenesis of Doyne honeycomb retinal dystrophy or Malattia leventnese. GPR75 is a member of the superfamily of transmembrane proteins that mediate signal transduction. Rhodopsin is also a member of this family. The potential functional properties of GPR75 and its expression in the retinal tissue have made this gene a candidate in AMD association studies. An analysis of 535 unrelated AMD patients and 252 matched controls identified a total of nine sequence alterations within this gene, three of which are believed to be polymorphic (Sauer et al., 2001). However, no statistical significance between these sequence variants and AMD risk was observed.

Schultz et al. (2003b)screened the single nucleotide polymorphism (SNP) (hemicentin - 1 Gln5345Arg) in sporadic AMD cases and found a very low frequency of 5345 Arg (1/188). However, they also found a similarly low frequency in random control subjects (2/174). Two 5345Arg carriers (aged 57 and 64 years) were found in the control population. One 5345Arg carrier (age 74 years at the time of diagnosis) was identified in the AMD cases (Schultz et al., 2003b). There are four hemicentin - 1 SNPs that are reported (Iyengar et al., 2004). Among the four, rs1475113, rs743137 and rs680638 account for the majority of the linkage (Section 3). The findings of this report further suggest that variants within or in very close proximity to this gene could be a factor in AMD pathogenesis. To what degree and by which mechanisms hemicentin - 1 plays a role in AMD pathogenesis are questions that remain to be answered.

A total of 43 sequence variants have been described in the human peripherin / RDS gene. Thirty-nine of these variants have been associated with retinal and macular phenotypes. The mutations associated with severe macular degeneration have been localized between the third and fourth transmembrane domains. Three of the amino acid polymorphisms of this gene, 
Glu338Gln, Lys310Arg, and Gly33Asp have a genotype frequency of approximately 50\% in the normal population (Keen and Inglehearn, 1996). These polymorphisms are located on the third exon of the peripherin / RDS gene. Silvestri (1997)screened 50 AMD patients and matched controls for variations within the peripherin/RDS gene. No disease-causing alteration was detected in either the case or control populations. Although associations have been made between peripherin / RDS mutations and polymorphisms and other retinal dystrophies, no similar associations have been found between these polymorphisms and AMD (Silvestri, 1997).

Although several genes have been identified as causative in other human macular disease phenotypes, none, with one possible exception, have been found in association with AMD. This exception is the causal gene of autosomal recessive juvenile-onset STGD1, ABCA4. The role of $A B C A 4$ in relation to AMD has been the subject of much debate and the focus of extensive study. These studies have generated a long series of conflicting reports. Heterozygous mutations in $A B C A 4$ have been associated with AMD in several studies (Allikmets et al., 1997a;Allikmets, 2000;Mata et al., 2001;Shroyer et al., 2001;Zhang et al., 1999); however, the significance of this association has been challenged.

The ABCA4 controversy began in 1997 when Allik-mets et al. (1997a) reported 13 different AMD-associated gene variations in one allele of $A B C A 4$. The AMD-associated alterations were scattered throughout the coding sequence of the $A B C A 4$ gene, although more were located towards the 3 'end. In their first study, 167 unrelated patients with AMD were screened, 26 (a significant $16 \%$ ) of whom were reported to carry a suspected disease-associated variation (Allikmets et al., 1997a). The most common ABCA4 variants identified by Allikmets et al. were $\mathrm{D} 2177 \mathrm{~N}$ and G1916E. The D2177N variant was reported as being significantly associated with AMD risk $(p=0.023)$. Allikmets et al. $(1997 \mathrm{a}, \mathrm{b})$ convincingly proposed that mutations in the $A B C A 4$ are associated with an increased risk of AMD. Allikmets later retested this hypothesis, that $A B C A 4$ is a dominant susceptibility locus for AMD, by screening 1218 unrelated AMD patients and 1258 controls for the two most frequent sequence variants, G1961E and D2177N. This study reported a statistical significance $(p<0.0001)$ between these two variants and AMD risk (Allikmets, 2000). Furthermore, they reported that the risk of AMD is elevated approximately threefold in $2177 \mathrm{~N}$ carriers and approximately fivefold in 1961E carriers (Allikmets, 2000). Further support was granted by a cohort study carried out by Shroyer et al. (2001)in which a complete sequence analysis of the $A B C A 4$ gene and tests of cosegregation in 22 families that manifest both STGD1 and AMD were carried out. Data from this study showed that STGD-causing mutations in $A B C A 4$ are associated with AMD (with a higher rate of AMD parents and grandparents of patients with STGD1 harboring ABCA4 variants, $\mathrm{p}=0.038$ ) and that $\mathrm{AMD}$-associated mutant $A B C A 4$ proteins have substantive defects in both expression and ATP binding (Shroyer et al., 2001). Additionally, Mata et al. (2001) developed a mouse model that shows that the absence of one $A B C A 4$ allele can lead to retinal degeneration. In this mouse model, mice heterozygous for $A B C A 4$ accumulate $\mathrm{A} 2 \mathrm{E}$ at a slower age-related rate and show severely delayed dark adaptation, a phenomenon which provides evidence of photoreceptor degradation and lipofuscin accumulation in the RPE (Mata et al., 2001). A2E is a major component of lipofuscin and an inhibitor of lysosomal proteolysis in RPE cells. A2E formation and accumulation occur as the result of $A B C A 4$ dysfunction or variation. A2E acts as a cationic detergent and dissolves cellular membranes when overexpressed in high concentrations (Mata et al., 2001). This accumulation may be deleterious to the RPE and to photoreceptors. A2E has also been shown to self-generate singlet oxygen upon irradiation which reacts with A2E to produce epoxides that damage DNA (Beatty et al., 2000).

Despite these findings, there have been several studies that did not find any statistical evidence for an association between either of the G1961E and D2177N alleles and AMD. Guymer et al. 
(2001)found no significant difference $(p>0.1)$ between 544 AMD patients and 689 controls. Furthermore, no evidence of cosegregation of these alleles and the AMD phenotype was observed in the examined five multiplex families with AMD. They did, however, find that the two $A B C A 4$ variant alleles were slightly more frequent in patients with the exudative form (or wet-type) of AMD versus those without this complication (2.7\% compared to $2.5 \%$, respectively) (Guymer et al., 2001). De La Paz et al. (1999)observed rates of ABCA4 variants significantly lower $(1.2 \%)$ than the rates Allikmets et al. reported $(16 \%, p=0.00001$; see above). Furthermore, the D2177N variant was only reported in two AMD sporadic individuals and this allele was not found in any of the familial AMD cases in this study. Interestingly, De La Paz et al. (1999)did report that a newly identified polymorphism, T190A, was found among all affected members of one of their larger AMD families although it failed to definitively segregate with the disease phenotype in another family. Similarly, several other independent reports found no evidence for significant association or cosegregation with the disease in family-based studies (Rivera et al., 2000;Schmidt et al., 2003;Souied et al., 2000;Stone et al., 1998; Webster et al., 2001). Thus, the true nature of $A B C A 4$ variation as a potential risk factor for AMD needs to be further evaluated.

\subsection{SNPs associated with the oxidative stress AMD pathway}

Oxygen consumption in the retina is much higher than in other human tissues (Beatty et al., 2000). The free radical theory of aging purports that age-related disorders arise as a result of oxidative stress, or the collective cellular damage caused by reactive oxygen species (ROS) (Beatty et al., 2000;Frank, 1998; Frank et al., 1999). The retina is particularly vulnerable to oxidative damage because of its high consumption of oxygen, the high proportion of polyunsaturated fatty acids in the outer segments of the RPE cells, and its high exposure to irradiation by visible light (Beatty et al., 2000). Thus, oxidative stress could potentially be a major pathway in AMD pathogenesis. Oxidized LDL levels are significantly higher in the plasma of AMD patients as compared to control subjects (Ikeda et al., 2001). In the presence of specific risk factors, genetic and/or environmental, an excess of oxidative damage may lead to pathological changes and disease. It has been hypothesized that the pathogenesis of AMD may involve the failure of the normal "oxidative protective" enzymes and mechanisms within the RPE to defend the macula against such stresses. Genetic variations within the antioxidants and mechanisms that provide protection against the effects of oxygen toxicity have been the focus of many AMD genetic association studies (For a summary, referTable 3).

Kimura et al. (2000)screened for polymorphic xenobiotic-metabolizing and antioxidant enzymes in Japanese populations afflicted with exudative (or wet-type) AMD. No association was established between AMD and the two polymorphisms, one located in the $3^{\prime}$-flanking region and one in exon 4, of the cytochrome P-450 1Al gene. Also, no association was established between AMD and the glutathione S-transferase theta 1, glutathione S-transferase $m \mu 1$, and microsomal epoxide hydrolase exon-4 polymorphisms. Allele frequency distribution of all five of these polymorphisms in AMD cases was similar to that found in the Japanese and Caucasian control populations (Kimura et al., 2000).

Kimura et al. (2000)did, however, report a statistically significant association between a polymorphism in the antioxidant enzyme manganese superoxide dismustase gene (MnSOD) and the exudative form of AMD. MnSOD is an isoform of superoxide dismustase 2 (SOD2). This gene encodes an intramitochondrial free radical scavenging enzyme preferentially expressed in the retina and believed to play an important role in tissue and cell protection against oxidative stress. Variation in this gene has been implicated in a wide range of degenerative processes. The $M n S O D$ polymorphism, which involves the substitution of a $\mathrm{C}$ from $\mathrm{T}$ at the -9 position in the mitochondrial targeting sequence, results in an increased and more efficient transport of the MnSOD protein into the mitochondria. The mitochondrion, a 
major producer of ROS, is itself subject to direct attack by these damaging radicals and is the main target of oxidative injury. This $M n S O D$ polymorphism causes a higher basal level of activity that results in excess hydrogen peroxide. The hydrogen peroxide then reacts with ferrous iron to form a surplus of cytotoxic hydroxyl radicals. These radicals can attack mitochondria and may promote the development of wet AMD. The same study also reported a weak association between microsomal epoxide hydrolase exon-3 (MEHE-3) and AMD (Kimura et al., 2000). The MEHE-3 enzyme catalyzes the hydrolysis of the epoxides derived from the oxidative metabolism of xenobiotic chemicals and pollutants. Both the MnSOD and MEHE-3 genes are expressed in the retina and the RPE cells (Behndig et al., 1998).

SNP association studies have also been carried out investigating the paraoxonase polymorphism. Immunohistochemical studies suggest that oxidative modified lipids and proteins play important roles in the pathogenesis of AMD. Paraoxonase is a polymorphic protein known to affect lipid metabolism as well as play a protective role against oxidative stress (Garin et al., 1997;Mackness et al., 1991;Ikeda et al., 2001). Specifically, paraoxonase is associated with high-density lipoprotein and has been shown to prevent LDL oxidation. Paraoxonase is a calcium-dependent glycoprotein. Two paraoxonase polymorphic sites, Glu192Arg and Leu54Met, have been studied in association with AMD. Both of these polymorphisms lead to different enzymatic activities, with the variant genotypes being associated with higher serum concentrations of the enzyme and, therefore, higher paraoxonase activity as well (Garin et al., 1997;Ikeda et al., 2001). Both the Glu192Arg and Leu54Met polymorphisms have been reported as being significantly associated with the risk of developing wet-type AMD in Japanese populations ( $p=0.0445$; and 0.0323, respectively) (Ikeda et al., 2001).

Metallothioneins (MTs) are also involved in the retinal antioxidant defense system. MTs, in their capacity as acute phase stress proteins, are believed to act as scavengers of active oxygen species and various radicals and protect cells from peroxidation (Sato et al., 2000). This protein also is believed to participate in the detoxification, metabolism, and homeostasis of some heavy metals, namely zinc, copper, and cadmium by binding and releasing them. MTs have also been implicated in the regulation of the cell proliferation process. It has been demonstrated that there is an age-related decline noted in the human macular RPE content of MTs (Beatty et al., 2000). At least six polymorphisms in the coding region of the $M T$ II gene and three in the $M T$ IA gene were found in the Japanese patients (Sato et al., 2000). However, no amino acid substitution was observed in these genes in Japanese patients nor was statistical significance established (Sato et al., 2000).

Efficient DNA repair mechanisms, particularly in the mitochondria, are necessary to maintain cellular integrity after oxidative damage has occurred (Liang and Godley, 2003). The disruption of DNA repair genes often leads to degenerative and earlier-onset age-related diseases such as the Werner and Bloom Syndromes. The human Oggl (hOggl) gene encodes a DNA glycosylase that is involved in the base excision pair of 8-hydroxy-2'-deoxyguanine (8-OH$\mathrm{dG})$ from oxidatively damaged DNA. The Ser326Cys of $h$ Ogg 1 SNP has been reported in association with certain kinds of cancer. The $C S B$ gene, also called ERCC6, is involved in the preferential repair in eukaryotes and collaborates with $h O g g l$ to carry out DNA repair (Tuo et al., 2001,2002a,b,2003). The CSB gene also plays a role in the mitochondrial repair of oxidative DNA damage. In our preliminary studies, no association has been found between either the Ser326Cys of $h O g g l$ or the CSB-promoter-6530C/G sequence variations and AMD (Bojanowski, unpublished data).

\subsection{SNPs that confer protection against AMD}

There have been reports on SNPs in genes believed to confer protection against AMD development (summarized inTable 4). The Alu polymorphism in the angiotensin-converting 
enzyme ( $A C E$ ) gene, localized to the retina, has previously been associated with the ocular disease proliferative diabetic retinopathy. Proliferative diabetic retinopathy is characterized by neovascular complications. For this reason, the $A C E$ polymorphism was hypothesized to be associated with the wet, or exudative, form of AMD (Hamdi et al., 2002). ACE is an enzyme known to catalyze the conversion of angiotensin I to angiotensin II. This enzyme is involved in electrolyte balance and blood pressure regulation and is implicated in cell proliferation and death in development and disease processes. This polymorphism, caused by an Alu insert, is believed to be responsible for the variable circulating level of ACE. No association was found between the ACE allelic and genotypic frequencies and the AMD case populations when compared to the control subjects. There was also, interestingly enough, no significant difference between the control and the neovascular/wet form of AMD case populations (Hamdi et al., 2002). However, upon further stratification, Hamdi et al. (2002)did find that the $A C E$ Alu+/+ genotype was 4.5 times more frequent in the control population than in the dry/atrophic form of AMD. Although, the exact mechanisms by which this ACE polymorphism might be linked to the pathology of AMD is not yet understood, these findings suggest a possible protective role of the polymorphism against the dry/atrophic form of AMD (Hamdi et al., 2002).

ApoE is an important regulator of cholesterol and lipid clearance and transport. This gene plays a pivotal role in the processes following central nervous system (CNS) injury, as it is responsible in part for neural plasticity and neuronal cell membrane maintenance and repair (Boyles et al., 1989;Poirier et al., 1993). Synthesized by astrocytes, the major glial cell of the CNS, ApoE is a major component of plasma and cerebrospinal fluid. ApoE or ApoE receptor dysfunction results in the accumulation of lipoproteins under certain conditions (Laws et al., 2003). The ApoE gene is known to be polymorphic (containing as many as 21 SNPs) with the occurrence of three common alleles; ApoE $\varepsilon 2$, ApoE $\varepsilon$ 3, and ApoE $\varepsilon 4$ (Laws et al., 2003). The most common allele, the e 3 allele, is considered to be the ancestral allele while the $\varepsilon 2$ and $\varepsilon 4$ alleles are considered as variants. These alleles encode three major isoforms $\varepsilon 2$

(Cys112,Cys158), $\varepsilon$ 3(Cys112,Arg158), $\varepsilon 4$ (Arg112, Arg158) which vary greatly in terms of protein structure and function (Laws et al., 2003;Schultz et al., 2003a).

The ApoE gene polymorphisms have been associated with genetic risk factors of various neurodegenerative diseases, most notably Alzheimer Disease (AD) (Laws et al., 2003). The epidemiological association of AMD to AD and similarities of some pathological features sparked the interest of the possible involvement of the $A p o E$ gene in AMD (Klaver et al., 1998a,1999). It has been hypothesized that the neuronal degeneration occurring in AMD and $\mathrm{AD}$ may, to some extent, have a common pathogenesis based on the recent finding of amyloid beta $(\hat{A} \beta)$, the major extracellular deposit in AD plaques, in drusen, the early hallmark of AMD (Dentchev et al., 2003). Á $\beta$ is hypothesized to increase the oxidative stress and inflammation expressed in AMD as it does in AD plaques (Dentchev et al., 2003). ApoE has also been shown to be a ubiquitous component of soft drusen, which arises from protein and lipid deposits within Bruch's membrane and is expressed in high concentrations in eyes affected by retinal damage (Dentchev et al., 2003). ApoE, therefore, is an intuitive candidate gene for AMD genetic studies both for its implicated role in AD and for its role in lipid metabolism.

Although there have been some contradictory reports (Schultz et al., 2003a), it is widely accepted that $A p o E$ is a susceptibility gene for AMD. The ApoE $\varepsilon 4$ isoform has been previously correlated with elevated cholesterol concentrations, stroke, and increased risk of coronary heart disease (Souied et al., 1998;Schultz et al., 2003a,b). However, $\varepsilon 4$ has been reported in association with a decreased risk of exudative AMD with soft drusen, with the $\varepsilon 4$ allele reported as being significantly less prevalent among wet AMD cases as compared with control populations (Klaver et al., 1998b;Schultz et al., 2003a;Souied et al., 1998). Klaver et al. (1998b) 
calculated that individuals that carry the $\varepsilon 4$ isoform were greater than 2 times less likely to develop AMD than were subjects with the $\varepsilon 2 \varepsilon 3$ genotype.

There have been two other studies that have further narrowed the proposed protective effect of the $\varepsilon 4$ allele. Schultz et al. (2003a)observed a trend toward a lower frequency of the $\varepsilon 4$ allele in only unrelated individuals with a family history of AMD. Later, Schmidt et al. (2000) found no evidence of $\varepsilon 4$ association with sporadic cases of AMD and further suggested that the protective effect of the e 4 allele is restricted to familial AMD cases only. While the $\varepsilon 4$ polymorphism is associated with a protective effect against AMD, the $\varepsilon 2$ allele has been associated with a slightly increased risk of late AMD. Studies have reported a weak causative role for the $\varepsilon 2$ allele in AMD with the frequency of the $\varepsilon 2$ allele higher, although not significantly, in AMD subjects (Klaver et al., 1998b;Simonelli et al., 2001). There has been no evidence for either a risk-increasing or risk-decreasing effect attributed to the $\varepsilon 3$ allele in either familial or sporadic cases of AMD.

\subsection{CX3CR1-implications for the possible immunological mechanisms behind AMD development and pathogenesis}

Recently, investigators have looked into the immunological mechanisms hypothesized to be involved with the development and pathogenesis of AMD. Macrophage dysfunction in clearing retinal deposits through the influence of chemoattraction has been a topic of particular interest and discussion (Ambati et al., 2003b;Espinosa-Heidmann et al., 2002). CX3CR1, a CX3C chemokine receptor of fraktaline, is known to be polymorphic with two non-synonymous SNPs in the open reading frame, V249I and T280M. Both of these variations ultimately result in reduced chemoattraction by lowering the binding affinity of the receptor to fractalkine and diminishing the number of available binding sites (McDermott et al., 2003).

In a preliminarily population-based study, we have found an association between the sequence variation of CX3CR1 (V249I and T280M) and AMD risk. CX3CR1-249I and 280M show an increased prevalence among AMD cases as compared to controls in a multiple control study (19.5\% 280M carriers in AMD over $11.4 \% 280 \mathrm{M}$ carriers in control, $\mathrm{OR}=1.81 ; p<0.05$ ) (Tuo et al., 2004). Furthermore, a dose-response between 249I/280M and AMD was demonstrated with 3.28 as the highest odds ratio. We compared the expression of CX3CRl mRNA in AMD macular and peripheral retinal cells from archived paraffin embedded slides. The transcripts of $C X 3 C R 1$ were undetectable in macula lesions but detectable in the normal peripheral retina cells (Tuo et al., 2004). While associations between 249I/280M and AMD exist, it seems unlikely that these variants affect the level of transcription directly. If the level of transcription is a true susceptibility factor, then the determinants may lie in the regulatory sites of CX3CR1, possibly in linkage disequilibrium with V249I and T280M. These variations might then serve as an intermediate trait. With such promising initial findings, investigating genes involved in the immunological mechanisms implicated in AMD development and pathogenesis has become an interesting potential avenue of research for future association studies.

These SNP association studies highlight some of the critical challenges that investigators face attempting to uncover the genetic component of not only AMD, but the genetic component of any complex disease. Complex diseases are marked by genetic heterogeneity, low penetrance, a continuous phenotypic distribution, and a high susceptibility to non-genetic factors. Failure to replicate results by independent groups is a major obstacle for advancement. Despite the limitations and difficulties historically associated with SNP analysis, there has been a renewed emphasis on association studies as they yield greater statistical power than linkage in the identification of disease gene loci of small effect. We must continue to rely on association studies to identify candidate genes and to test out various hypotheses.

Prog Retin Eye Res. Author manuscript; available in PMC 2007 August 20. 


\section{Perspectives}

Uncovering the genetic risk factors for AMD is imperative for future progress in the battle against this disorder. Identification of AMD's genetic causes will allow investigators and clinicians to develop better definitions and characterizations of the disease phenotypes. In addition, determination of genetic risk factors may contribute to a better understanding of the pathogenesis of this disease. These advances will greatly impact clinical treatment as well as direct the application of molecular manipulation and preventive interference. Progress has already been made in the development of potential treatments based on several of the factors that have been reviewed in this paper. For example, based on the correlation of the peripherin/ $R D S$ with retinitis pigmentosa and AMD, subretinal injections of recombinant adenoassociated virus encoding a peripherin/RDS transgene have been investigated with promising findings in mice (Ali et al., 2000). These injections result in the generation of outer-segment structures and the formation of new stacks of discs containing both peripherin /RDS and rhodopsin thus preserving electrophysiological functions in retinal degeneration slow (peripherin/RDS null) mice. Another potential treatment involves the oral administration of long chain fatty acids to AMD patients based on the studies of ELOVL4 in AMD (Ayyagarri R., NEI Seminar 2003).

During the preparation for this review, it became evident that there is no consensus in the ophthalmologic and genetic communities regarding the identification of definitive AMDrelated loci, genes, and sequence variants. The AMD loci obtained from whole genome scans cover only a fraction of the genes identified in monogenic retinal diseases, animal models, and gene variation studies (seeTables 1-4). Sequence variants in the genes identified from monogenic retinal and macular disorders have not proven to be associated with AMD, with the possible exception of $A B C A 4$. Progress in the study of AMD genetics has been delayed and greatly confounded by the intrinsic complex nature of the disease and the considerable impact of environmental factors on disease development and progression. Examples of the difficulties involved in conducting these genetic studies include; varying phenotypes, continuous distribution within a phenotype, uncertain modes of inheritance, low lod scores in linkage, similar linkage evidence but in non-identical loci from different studies, and continuous distribution of associated traits (SNP) in AMD cases as well as in controls. In addition, the disease is also strongly influenced by, and interacts with, many non-genetic factors. Clearly, the solution to the AMD genetic problem will be much harder to solve than we imagined.

Even though results have been controversial and inconsistent so far, it is generally believed that association studies are still applicable to complex diseases such as AMD. While only a limited number of related genes and SNPs within genes have been tested for association with AMD, the current lack of evidence for association does not completely exclude the involvement of these genes in AMD development. Bias is another problem of AMD association studies. However, bias can be limited by careful study design. Since AMD is age-dependent and of a high incidence, multiple control groups with different average ages can be used to elucidate a possible dose-response of the tested genetic risk. This design is compensatory in studies with small sample sizes. Well-defined phenotyping, disease scoring, and continuous studies in a cohort will also be invaluable to the quantitative analyses of genetic donation and stratification. In addition, efficient information can be obtained from a well-matched case-control study with minimal ethnic differences. Finally, family-based designs that involve typing both affected and consanguineous individuals could also remove the possible confounding factor of ethnicity (Brennan, 2002).

In AMD, as in other complex diseases, the role of genetics is thought to be the result of the combined effects exerted by multiple gene variants and their interaction with environmental 
factors. Therefore, the interaction between the environment and genes cannot be ignored during our search for AMD gene variants. Environmental components could trigger the AMD phenotype in genetically predisposed individuals. A family-based design with spouse involvement could be an effective way to limit confounding environmental factors. Quantitative interpretations of the confounders could greatly help in the search to determine the extent that these environmental factors contribute to the development of AMD.

Interestingly, many products of the genes discussed above were detected either by immunohistochemistry or proteomics in human AMD drusen specimens or animal models. These include TIMP3, ApoE, collagen, etc. (Ambati et al., 2003b;Crabb et al., 2002;Mullins et al., 2000). The elucidation of the molecular mechanisms of the accumulation of the gene products in the retina could further confirm or obviate the roles of these genes in AMD.

One of our aims is to genetically screen individuals at an early age and assess their genetic predisposition of developing AMD in order to provide effective interference at an optimal time. If genetic predisposition is discovered at an early age, behavioral styles can be modified to curtail or even completely avoid the devastating effects of macular degeneration later in life. Current evidence has shown that it seems highly unlikely that a single gene variant is solely responsible for the development of AMD, at least not in the common forms of the disease. Perhaps focusing on the dynamic interaction between multiple genes, gene-environmental components and their comprehensive effects will provide new insights in the search for the genetic risks, pathogenesis and treatment of AMD.

\section{Acknowledgements}

We would like to thank Dr. Fielding J. Hejtmancik for critical review.

\section{References}

Age-Related Eye Disease Study Research Group. Risk factors associated with age-related macular degeneration. A case-control study in the age-related eye disease study: age-related eye disease study report number 3, Age-Related Eye Disease Study Research Group. Ophthalmology 2000;107:22242232. [PubMed: 11097601]

Age-Related Eye Disease Study Research Group. A randomized, placebo-controlled, clinical trial of highdose supplementation with vitamins $\mathrm{C}$ and $\mathrm{E}$, beta carotene, and zinc for age-related macular degeneration and vision loss: AREDS Report No. 8. Arch Ophthalmol 2001;119:1417-1436. [PubMed: 11594942]

Akimoto A, Akimoto M, Kuroiwa S, Kikuchi T, Yoshimura N. Lack of association of mutations of the bestrophin gene with age-related macular degeneration in non-familial Japanese patients. Graefes Arch Clin Exp Ophthalmol 2001;239:66-68. [PubMed: 11271465]

Ali RR, Sarra GM, Stephens C, Alwis MD, Bainbridge JW, Munro PM, et al. Restoration of photoreceptor ultrastructure and function in retinal degeneration slow mice by gene therapy. Nat Genet 2000;25:306310. [PubMed: 10888879]

Allikmets R. Further evidence for an association of ABCR alleles with age-related macular degeneration. The International ABCR Screening Consortium. Am J Hum Genet 2000;67:487-491. [PubMed: 10880298]

Allikmets R, Shroyer NF, Singh N, Seddon JM, Lewis RA, Bernstein PS, et al. Mutation of the Stargardt disease gene (ABCR) in age-related macular degeneration. Science 1997a;277:1805-1807. [PubMed: 9295268]

Allikmets R, Singh N, Sun H, Shroyer NF, Hutchinson A, Chidambaram A, et al. A photoreceptor cellspecific ATP-binding transporter gene (ABCR) is mutated in recessive Stargardt macular dystrophy. Nat Genet 1997b;15:236-246. [PubMed: 9054934]

Allikmets R, Seddon JM, Bernstein PS, Hutchinson A, Atkinson A, Sharma S, et al. Evaluation of the Best disease gene in patients with age-related macular degeneration and other maculopathies. Hum Genet 1999;104:449-453. [PubMed: 10453731] 
Ambati J, Ambati BK, Yoo SH, Ianchulev S, Adamis AP. Age-related macular degeneration: etiology, pathogenesis, and therapeutic strategies. Surv Ophthalmol 2003a;48:257-293. [PubMed: 12745003]

Ambati J, Anand A, Fernandez S, Sakurai E, Lynn BC, Kuziel WA, et al. An animal model of age-related macular degeneration in senescent Ccl-2- or Ccr-2-deficient mice. Nat Med 2003b;9:1309-1398.

Anand-Apte B, Pepper MS, Voest E, Montesano R, Olsen B, Murphy G, et al. Inhibition of angiogenesis by tissue inhibitor of metalloproteinase-3. Invest Ophthalmol Vis Sci 1997;38:817-823. [PubMed: 9112976]

Apfelstedt-Sylla E, Theischen M, Ruther K, Wedemann H, Gal A, Zrenner E. Extensive intrafamilial and interfamilial phenotypic variation among patients with autosomal dominant retinal dystrophy and mutations in the human RDS/peripherin gene. Br J Ophthalmol 1995;79:28-34. [PubMed: 7880786]

Ayyagari R, Zhang K, Hutchinson A, Yu Z, Swaroop A, Kakuk LE, et al. Evaluation of the ELOVL4 gene in patients with age-related macular degeneration. Ophthalmic Genet 2001;22:233-239. [PubMed: 11803489]

Azarian SM, Travis GH. The photoreceptor rim protein is an ABC transporter encoded by the gene for recessive Stargardt's disease (ABCR). FEBS Lett 1997;409:247-252. [PubMed: 9202155]

Beatty S, Koh H, Phil M, Henson D, Boulton M. The role of oxidative stress in the pathogenesis of agerelated macular degeneration. Surv Ophthalmol 2000;45:115-134. [PubMed: 11033038]

Behndig A, Svensson B, Marklund SL, Karlsson K. Superoxide dismutase isoenzymes in the human eye. Invest Ophthalmol Vis Sci 1998;39:471-475. [PubMed: 9501855]

Birnbach CD, Jarvelainen M, Possin DE, Milam AH. Histopathology and immunocytochemistry of theneurosensory retina in fundus flavimaculatus. Ophthalmology 1994;101:1211-1219. [PubMed: 8035984]

Boyles JK, Zoellner CD, Anderson LJ, Kosik LM, Pitas RE, Weisgraber KH, et al. A role for apolipoprotein E, apolipoprotein A-I, and low density lipoprotein receptors in cholesterol transport during regeneration and remyelination of the rat sciatic nerve. J Clin Invest 1989;83:1015-1031. [PubMed: 2493483]

Brennan P. Gene-environment interaction and aetiology of cancer: what does it mean and how can we measure it? Carcinogenesis 2002;23:381-387. [PubMed: 11895852]

Capon MR, Marshall J, Krafft JI, Alexander RA, Hiscott PS, Bird AC. Sorsby’s fundus dystrophy. A light and electron microscopic study. Ophthalmology 1989;96:1769-1777. [PubMed: 2482957]

Carrero-Valenzuela RD, Klein ML, Weleber RG, Murphey WH, Litt M. Sorsby fundus dystrophy. A family with the Ser181Cys mutation of the tissue inhibitor of metalloproteinases 3. Arch Ophthalmol 1996;114:737-738. [PubMed: 8639088]

Chader GJ. Animal models in research on retinal degenerations: past progress and future hope. Vis Res 2002;42:393-399. [PubMed: 11853755]

Chang B, Heckenlively JR, Hawes NL, Roderick TH. New mouse primary retinal degeneration rd-3. Genomics 1993;16:45-49. [PubMed: 8486383]

Chang B, Bronson RT, Hawes NL, Roderick TH, Peng C, Hageman GS, Heckenlively JR. Retinal degeneration in motor neuron degeneration: a mouse model of ceroid lipofuscinosis. Invest Ophthalmol Vis Sci 1994;35:1071-1076. [PubMed: 8125718]

Chang B, Hawes NL, Hurd RE, Davisson MT, Nusinowitz S, Heckenlively JR. Retinal degeneration mutants in the mouse. Vis Res 2002;42:517-525. [PubMed: 11853768]

Chong NH, Alexander RA, Gin T, Bird AC, Luthert PJ. TIMP-3, collagen, and elastin immunohistochemistry and histopathology of Sorsby's fundus dystrophy. Invest Ophthalmol Vis Sci 2000;41:898-902. [PubMed: 10711711]

Ciardella AP, Donsoff IM, Guyer DR, Adamis A, Yannuzzi LA. Antiangiogenesis agents. Ophthalmol Clin N Am 2002;15:453-458.

Crabb JW, Miyagi M, Gu X, Shadrach K, West KA, Sakaguchi H, et al. Drusen proteome analysis: an approach to the etiology of age-related macular degeneration. Proc Natl Acad Sci USA 2002;99:14682-14687. [PubMed: 12391305]

de Jong PT, Klaver CC, Wolfs RC, Assink JJ, Hofman A. Familial aggregation of age-related maculopathy. Am J Ophthalmol 1997;124:862-863. [PubMed: 9402844] 
De La Paz MA, Pericak-Vance MA, Lennon F, Haines JL, Seddon JM. Exclusion of TIMP3 as a candidate locus in age-related macular degeneration. Invest Ophthalmol Vis Sci 1997;38:1060-1065. [PubMed: 9152225]

De La Paz MA, Guy VK, Abou-Donia S, Heinis R, Bracken B, Vance JM, et al. Analysis of the Stargardt disease gene (ABCR) in age-related macular degeneration. Ophthalmology 1999;106:1531-1536. [PubMed: 10442900]

Delcourt C, Michel F, Colvez A, Lacroux A, Delage M, Vernet MH. Associations of cardiovascular disease and its risk factors with age-related macular degeneration: the POLA study. Ophthal Epidemiol 2001;8:237-249.

Demant P, Ivanyi D, van Nie R. The map position of the rds gene on the 17 th chromosome of the mouse. Tissue Antigens 1979;13:53-55. [PubMed: 419532]

Dentchev T, Milam AH, Lee VM, Trojanowski JQ, Dunaief JL. Amyloid-beta is found in drusen from some age-related macular degeneration retinas, but not in drusen from normal retinas. Mol Vis 2003;9:184-190. [PubMed: 12764254]

Dithmar S, Curcio CA, Le NA, Brown S, Grossniklaus HE. Ultrastructural changes in Bruch's membrane of apolipoprotein E-deficient mice. Invest Ophthalmol Vis Sci 2000;41:2035-2042. [PubMed: 10892840]

Downes SM, Fitzke FW, Holder GE, Payne AM, Bessant DA, Bhattacharya SS, Bird AC. Clinical features of codon 172 RDS macular dystrophy: similar phenotype in 12 families. Arch Ophthalmol 1999;117:1373-1383. [PubMed: 10532447]

Ekstrom U, Andreasson S, Ponjavic V, Abrahamson M, Sandgren O, Nilsson-Ehle P, Ehinger B. A Swedish family with a mutation in the peripherin/RDS gene (Arg-172-Trp) associated with a progressive retinal degeneration. Ophthal Genet 1998;19:149-156.

Espinosa-Heidmann DG, Suner I, Hernandez EP, Frazier WD, Csaky KG, Cousins SW. Age as an independent risk factor for severity of experimental choroidal neovascularization. Invest Ophthalmol Vis Sci 2002;43:1567-1573. [PubMed: 11980875]

Felbor U, Stohr H, Amann T, Schonherr U, Apfelstedt-Sylla E, Weber BH. A second independent Tyr168Cys mutation in the tissue inhibitor of metalloproteinases-3 (TIMP3) in Sorsby's fundus dystrophy. J Med Genet 1996;33:233-236. [PubMed: 8728699]

Felbor U, Doepner D, Schneider U, Zrenner E, Weber BH. Evaluation of the gene encoding the tissue inhibitor of metalloproteinases-3 in various maculopathies. Invest Ophthalmol Vis Sci 1997;38:1054-1059. [PubMed: 9152224]

Fine SL, Berger JW, Maguire MG, Ho AC. Age-related macular degeneration. N Engl J Med 2000;342:483-492. [PubMed: 10675430]

Frangieh GT, Green WR, Fine SL. A histopathologic study of Best's macular dystrophy. Arch Ophthalmol 1982;100:1115-1121. [PubMed: 7092655]

Frank RN. "Oxidative protector'" enzymes in the macular retinal pigment epithelium of aging eyes and eyes with age-related macular degeneration. Trans Am Ophthalmol Soc 1998;96:635-689. [PubMed: 10360305]

Frank RN, Amin RH, Puklin JE. Antioxidant enzymes in the macular retinal pigment epithelium of eyes with neovascular age-related macular degeneration. Am J Ophthalmol 1999;127:694-709. [PubMed: 10372880]

Friedman DS, Katz J, Bressler NM, Rahmani B, Tielsch JM. Racial differences in the prevalence of agerelated macular degeneration: the Baltimore Eye Survey. Ophthalmology 1999;106:1049-1055. [PubMed: 10366070]

Fujii GY, De Juan E Jr, Humayun MS, Chang TS. Limited macular translocation for the management of subfoveal choroidal neovascularization after photodynamic therapy. Am J Ophthalmol 2003;135:109-112. [PubMed: 12504715]

Garin MC, James RW, Dussoix P, Blanche H, Passa P, Froguel P, Ruiz J. Paraoxonase polymorphism Met-Leu54 is associated with modified serum concentrations of the enzyme. A possible link between the paraoxonase gene and increased risk of cardiovascular disease in diabetes. J Clin Invest 1997;99:62-66. [PubMed: 9011577] 
Gottfredsdottir MS, Sverrisson T, Musch DC, Stefansson E. Age related macular degeneration in monozygotic twins and their spouses in Iceland. Acta Ophthalmol Scand 1999;77:422-425. [PubMed: 10463414]

Gouras P, Kong J, Tsang SH. Retinal degeneration and RPE transplantation in Rpe65(-/-) mice. Invest Ophthalmol Vis Sci 2002;43:3307-3311. [PubMed: 12356839]

Gregory-Evans K. What is Sorsby's fundus dystrophy? Br J Ophthalmol 2000;84:679-680. [PubMed: 10873972]

Gulcher J, Kong A, Stefansson K. The genealogic approach to human genetics of disease. Cancer J 2001;7:61-68. [PubMed: 11269649]

Guymer R. The genetics of age-related macular degeneration. Clin Exp Optom 2001;84:182-189. [PubMed: 12366313]

Guymer RH, Heon E, Lotery AJ, Munier FL, Schorderet DF, Baird PN, et al. Variation of codons 1961 and 2177 of the Stargardt disease gene is not associated with age-related macular degeneration. Arch Ophthalmol 2001;119:745-751. [PubMed: 11346402]

Guymer RH, McNeil R, Cain M, Tomlin B, Allen PJ, Dip CL, Baird PN. Analysis of the Arg345Trp disease-associated allele of the EFEMP1 gene in individuals with early onset drusen or familial agerelated macular degeneration. Clin Exp Ophthalmol 2002;30:419-423.

Hageman GS, Luthert PJ, Victor Chong NH, Johnson LV, Anderson DH, Mullins RF. An integrated hypothesis that considers drusen as biomarkers of immune-mediated processes at the RPE-Bruch's membrane interface in aging and age-related macular degeneration. Prog Retin Eye Res 2001;20:705-732. [PubMed: 11587915]

Halushka MK, Fan JB, Bentley K, Hsie L, Shen N, Weder A, et al. Patterns of single-nucleotide polymorphisms in candidate genes for blood-pressure homeostasis. Nat Genet 1999;22:239-247. [PubMed: 10391210]

Hamdi HK, Reznik J, Castellon R, Atilano SR, Ong JM, Udar N, et al. Alu DNA polymorphism in ACE gene is protective for age-related macular degeneration. Biochem Biophys Res Commun 2002;295:668-672. [PubMed: 12099691]

Hamel CP, Tsilou E, Pfeffer BA, Hooks JJ, Detrick B, Redmond TM. Molecular cloning and expression of RPE65, a novel retinal pigment epithelium-specific microsomal protein that is posttranscriptionally regulated in vitro. J Biol Chem 1993;268:15751-15757. [PubMed: 8340400]

Hamel CP, Jenkins NA, Gilbert DJ, Copeland NG, Redmond TM. The gene for the retinal pigment epithelium-specific protein RPE65 is localized to human 1p31 and mouse 3. Genomics 1994;20:509512. [PubMed: 8034329]

Hawes NL, Chang B, Hageman GS, Nusinowitz S, Nishina PM, Schneider BS, et al. Retinal degeneration 6 (rd6): a new mouse model for human retinitis punctata albescens. Invest Ophthalmol Vis Sci 2000;41:3149-3157. [PubMed: 10967077]

Hayward C, Shu X, Cideciyan AV, Lennon A, Barran P, Zareparsi S, et al. Mutation in a short-chain collagen gene, CTRP 5, results in extracellular deposit formation in late-onset retinal degeneration: a genetic model for age-related macular degeneration. Hum Mol Genet 2003;12:2657-2667. [PubMed: 12944416]

Heckenlively JR, Winston JV, Roderick TH. Screening for mouse retinal degenerations. I. Correlation of indirect ophthalmoscopy, electroretinograms, and histology. Doc Ophthalmol 1989;71:229-239. [PubMed: 2776628]

Heon E, Piguet B, Munier F, Sneed SR, Morgan CM, Forni S, et al. Linkage of autosomal dominant radial drusen (Malattia leventinese) to chromosome 2p16-21. Arch Ophthalmol 1996;114:193-198. [PubMed: 8573024]

Husain D, Ambati B, Adamis AP, Miller JW. Mechanisms of age-related macular degeneration. Ophthalmol Clin N Am 2002;15:87-91.

Hyman L, Neborsky R. Risk factors for age-related macular degeneration: an update. Curr Opin Ophthalmol 2002;13:171-175. [PubMed: 12011686]

Ikeda T, Obayashi H, Hasegawa G, Nakamura N, Yoshikawa T, Imamura Y, et al. Paraoxonase gene polymorphisms and plasma oxidized low-density lipoprotein level as possible risk factors for exudative age-related macular degeneration. Am J Ophthalmol 2001;132:191-195. [PubMed: $11476678]$ 
Iyengar SK, Song D, Klein BE, Klein R, Schick JH, Humphrey J, et al. Dissection of genomewide-scan data in extended families reveals a major locus and oligogenic susceptibility for age-related macular degeneration. Am J Hum Genet 2004;74:20-39. [PubMed: 14691731]

Jacobson SG, Cideciyan AV, Wright E, Wright AF. Phenotypic marker for early disease detection in dominant late-onset retinal degeneration. Invest Ophthalmol Vis Sci 2001;42:1882-1890. [PubMed: 11431457]

Jacobson SG, Cideciyan AV, Bennett J, Kingsley RM, Sheffield VC, Stone EM. Novel mutation in the TIMP3 gene causes Sorsby fundus dystrophy. Arch Ophthalmol 2002;120:376-379. [PubMed: 11879143]

Kamei M, Hollyfield JG. TIMP-3 in Bruch's membrane: changes during aging and in age-related macular degeneration. Invest Ophthalmol Vis Sci 1999;40:2367-2375. [PubMed: 10476804]

Kameya S, Hawes NL, Chang B, Heckenlively JR, Naggert JK, Nishina PM. Mfrp, a gene encoding a frizzled related protein, is mutated in the mouse retinal degeneration. Hum Mol Genet 2002;11:18791886. [PubMed: 12140190]

Kaplan J, Gerber S, Larget-Piet D, Rozet JM, Dollfus H, Dufier JL, et al. A gene for Stargardt's disease (fundus flavimaculatus) maps to the short arm of chromosome 1. Nat Genet 1993;5:308-311. [PubMed: 8275096]

Katz ML, Redmond TM. Effect of Rpe65 knockout on accumulation of lipofuscin fluorophores in the retinal pigment epithelium. Invest Ophthalmol Vis Sci 2001;42:3023-3030. [PubMed: 11687551]

Keen TJ, Inglehearn CF. Mutations and polymorphisms in the human peripherin-RDS gene and their involvement in inherited retinal degeneration. Hum Mutat 1996;8:297-303. [PubMed: 8956033]

Kenealy SJ, Schmidt S, Agarwal A, Postel EA, De La Paz MA, Pericak-Vance MA, et al. Linkage analysis for age-related macular degeneration supports a gene on chromosome 10q26. Mol Vis 2004;10:5761. [PubMed: 14758336]

Kennedy CJ, Rakoczy PE, Constable IJ. Lipofuscin of the retinal pigment epithelium: a review. Eye 1995;9(Pt 6):763-771. [PubMed: 8849547]

Khani SC, Karoukis AJ, Young JE, Ambasudhan R, Burch T, Stockton R, et al. Late-onset autosomal dominant macular dystrophy with choroidal neovascularization and nonexudative maculopathy associated with mutation in the RDS gene. Invest Ophthalmol Vis Sci 2003;44:3570-3577. [PubMed: 12882809]

Kimura K, Isashiki Y, Sonoda S, Kakiuchi-Matsumoto T, Ohba N. Genetic association of manganese superoxide dismutase with exudative age-related macular degeneration. Am J Ophthalmol 2000;130:769-773. [PubMed: 11124296]

Kini MM, Leibowitz HM, Colton T, Nickerson RJ, Ganley J, Dawber TR. Prevalence of senile cataract, diabetic retinopathy, senile macular degeneration, and open-angle glaucoma in the Framingham eye study. Am J Ophthalmol 1978;85:28-34. [PubMed: 619683]

Klaver CC, Kliffen M, van Duijn CM, Hofman A, Cruts M, Grobbee DE, et al. Genetic association of apolipoprotein E with age-related macular degeneration. Am J Hum Genet 1998a;63:200-206. [PubMed: 9634502]

Klaver CC, Wolfs RC, Assink JJ, van Duijn CM, Hofman A, de Jong PT. Genetic risk of age-related maculopathy. Population-based familial aggregation study. Arch Ophthalmol 1998b;116:16461651. [PubMed: 9869796]

Klaver CC, Ott A, Hofman A, Assink JJ, Breteler MM, de Jong PT. Is age-related maculopathy associated with Alzheimer's Disease? The Rotterdam Study. Am J Epidemiol 1999;150:963-968. [PubMed: 10547142]

Klein ML, Schultz DW, Edwards A, Matise TC, Rust K, Berselli CB, et al. Age-related macular degeneration.Clinical features in a large family and linkage to chromosome 1q. Arch Ophthalmol 1998;116:1082-1088. [PubMed: 9715689]

Kliffen M, van der Schaft TL, Mooy CM, de Jong PT. Morphologic changes in age-related maculopathy. Microsc Res Technol 1997;36:106-122.

Kliffen M, Lutgens E, Daemen MJ, de Muinck ED, Mooy CM, de Jong PT. The APO(*)E3-Leiden mouse as an animal model for basal laminar deposit. Br J Ophthalmol 2000;84:1415-1419. [PubMed: 11090485] 
Kniazeva M, Traboulsi EI, Yu Z, Stefko ST, Gorin MB, Shugart YY, et al. A new locus for dominant drusen and macular degeneration maps to chromosome 6q14. Am J Ophthalmol 2000;130:197-202. [PubMed: 11004294]

Kohl S, Giddings I, Besch D, Apfelstedt-Sylla E, Zrenner E, Wissinger B. The role of the peripherin/ RDS gene in retinal dystrophies. Acta Anat (Basel) 1998;162:75-84. [PubMed: 9831753]

Kornzweig AL. The eye in old age. V. Diseases of the macula: a clinicopathologic study. Am J Ophthalmol 1965;60:835-843. [PubMed: 5844910]

Kramer F, White K, Pauleikhoff D, Gehrig A, Passmore L, Rivera A, et al. Mutations in the VMD2 gene are associated with juvenile-onset vitelliform macular dystrophy (Best disease) and adult vitelliform macular dystrophy but not age-related macular degeneration. Eur J Hum Genet 2000;8:286-292. [PubMed: 10854112]

Kramer F, Mohr N, Kellner U, Rudolph G, Weber BH. Ten novel mutations in VMD2 associated with Best macular dystrophy (BMD). Hum Mutat 2003;22:418. [PubMed: 14517959]

Kuntz CA, Jacobson SG, Cideciyan AV, Li ZY, Stone EM, Possin D, Milam AH. Sub-retinal pigment epithelial deposits in a dominant late-onset retinal degeneration. Invest Ophthalmol Vis Sci 1996;37:1772-1782. [PubMed: 8759344]

la Cour M, Kiilgaard JF, Nissen MH. Age-related macular degeneration: epidemiology and optimal treatment. Drugs Aging 2002;19:101-133. [PubMed: 11950377]

Lander E, Kruglyak L. Genetic dissection of complex traits: guidelines for interpreting and reporting linkage results. Nat Genet 1995;11:241-247. [PubMed: 7581446]

Laws SM, Hone E, Gandy S, Martins RN. Expanding the association between the APOE gene and the risk of Alzheimer's disease: possible roles for APOE promoter polymorphisms and alterations in APOE transcription. J Neurochem 2003;84:1215-1236. [PubMed: 12614323]

Lecka-Czernik B, Lumpkin CK Jr, Goldstein S. An overexpressed gene transcript in senescent and quiescent human fibroblasts encoding a novel protein in the epidermal growth factor-like repeat family stimulates DNA synthesis. Mol Cell Biol 1995;15:120-128. [PubMed: 7799918]

Li Y, Marcos I, Borrego S, Yu Z, Zhang K, Antinolo G. Evaluation of the ELOVL4 gene in families with retinitis pigmentosa linked to the RP25 locus. J Med Genet 2001;38:478-480. [PubMed: 11474659]

Liang FQ, Godley BF. Oxidative stress-induced mitochondrial DNA damage in human retinal pigment epithelial cells: a possible mechanism for RPE aging and age-related macular degeneration. Exp Eye Res 2003;76:397-403. [PubMed: 12634104]

Lim JI. Photodynamic therapy for choroidal neovascular disease: photosensitizers and clinical trials. Ophthalmol Clin N Am 2002;15:473-478.

Lith-Verhoeven JJ, Cremers FP, van den HB, Hoyng CB, Deutman AF. Genetic heterogeneity of butterfly-shaped pigment dystrophy of the fovea. Mol Vis 2003a;9:138-143. [PubMed: 12724643]

Lith-Verhoeven JJ, van den HB, Deutman AF, Bergen AA, Cremers FP, Hoyng CB, de Jong PT. A peculiar autosomal dominant macular dystrophy caused by an asparagine deletion at codon 169 in the peripherin/RDS gene. Arch Ophthalmol 2003b;121:1452-1457. [PubMed: 14557182]

Lotery AJ, Munier FL, Fishman GA, Weleber RG, Jacobson SG, Affatigato LM, et al. Allelic variation in the VMD2 gene in best disease and age-related macular degeneration. Invest Ophthalmol Vis Sci 2000;41:1291-1296. [PubMed: 10798642]

Lutty G, Grunwald J, Majji AB, Uyama M, Yoneya S. Changes in choriocapillaris and retinal pigment epithelium in age-related macular degeneration. Mol Vis 1999;5:35. [PubMed: 10562659]

Mackness MI, Arrol S, Durrington PN. Paraoxonase prevents accumulation of lipoperoxides in lowdensity lipoprotein. FEBS Lett 1991;286:152-154. [PubMed: 1650712]

Majewski J, Schultz DW, Weleber RG, Schain MB, Edwards AO, Matise TC, et al. Age-related macular degeneration-a genome scan in extended families. Am J Hum Genet 2003;73:540-550. [PubMed: 12900797]

Majid MA, Smith VA, Easty DL, Baker AH, Newby AC. Sorsby's fundus dystrophy mutant tissue inhibitors of metalloproteinase-3 induce apoptosis of retinal pigment epithelial and MCF-7 cells. FEBS Lett 2002;529:281-285. [PubMed: 12372614]

Marmorstein LY, Munier FL, Arsenijevic Y, Schorderet DF, McLaughlin PJ, Chung D, et al. Aberrant accumulation of EFEMP1 underlies drusen formation in Malattia leventinese and age-related macular degeneration. Proc Natl Acad Sci USA 2002;99:13067-13072. [PubMed: 12242346] 
Marquardt A, Stohr H, Passmore LA, Kramer F, Rivera A, Weber BH. Mutations in a novel gene, VMD 2, encoding a protein of unknown properties cause juvenile-onset vitelliform macular dystrophy (Best's disease). Hum Mol Genet 1998;7:1517-1525. [PubMed: 9700209]

Mata NL, Tzekov RT, Liu X, Weng J, Birch DG, Travis GH. Delayed dark-adaptation and lipofuscin accumulation in abcr+/3 mice: implications for involvement of ABCR in age-related macular degeneration. Invest Ophthalmol Vis Sci 2001;42:1685-1690. [PubMed: 11431429]

Maw MA, Corbeil D, Koch J, Hellwig A, Wilson-Wheeler JC, Bridges RJ, et al. A frameshift mutation in prominin (mouse)-like 1 causes human retinal degeneration. Hum Mol Genet 2000;9:27-34. [PubMed: 10587575]

McBee WL, Lindblad AS, Ferris FL III. Who should receive oral supplement treatment for age-related macular degeneration? Curr Opin Ophthalmol 2003;14:159-162. [PubMed: 12777936]

McDermott DH, Fong AM, Yang Q, Sechler JM, Cupples LA, Merrell MN, et al. Chemokine receptor mutant CX3CR1-M280 has impaired adhesive function and correlates with protection from cardiovascular disease in humans. J Clin Invest 2003;111:1241-1250. [PubMed: 12697743]

Meyers SM, Greene T, Gutman FA. A twin study of age-related macular degeneration. Am J Ophthalmol 1995;120:757-766. [PubMed: 8540549]

Michaelides M, Hunt DM, Moore AT. The genetics of inherited macular dystrophies. J Med Genet 2003;40:641-650. [PubMed: 12960208]

Milam AH, Curcio CA, Cideciyan AV, Saxena S, John SK, Kruth HS, et al. Dominant late-onset retinal degeneration with regional variation of sub-retinal pigment epithelium deposits, retinal function, and photoreceptor degeneration. Ophthalmology 2000;107:2256-2266. [PubMed: 11097607]

Mousa SA, Lorelli W, Campochiaro PA. Role of hypoxia and extracellular matrix-integrin binding in the modulation of angiogenic growth factors secretion by retinal pigmented epithelial cells. J Cell Biochem 1999;74:135-143. [PubMed: 10381270]

Mullins RF, Russell SR, Anderson DH, Hageman GS. Drusen associated with aging and age-related macular degeneration contain proteins common to extracellular deposits associated with atherosclerosis, elastosis, amyloidosis, and dense deposit disease. FASEB J 2000;14:835-846. [PubMed: 10783137]

Nakazawa M, Wada Y, Tamai M. Macular dystrophy associated with monogenic Arg172Trp mutation of the peripherin/ RDS gene in a Japanese family. Retina 1995;15:518-523. [PubMed: 8747448]

Nichols BE, Drack AV, Vandenburgh K, Kimura AE, Sheffield VC, Stone EM. A 2 base pair deletion in the RDS gene associated with butterfly-shaped pigment dystrophy of the fovea. Hum Mol Genet 1993a;2:1347. [PubMed: 8401530]

Nichols BE, Sheffield VC, Vandenburgh K, Drack AV, Kimura AE, Stone EM. Butterfly-shaped pigment dystrophy of the fovea caused by a point mutation in codon 167 of the RDS gene. Nat Genet 1993b; 3:202-207. [PubMed: 8485574]

Payne AM, Downes SM, Bessant DA, Bird AC, Bhattacharya SS. Founder effect, seen in the British population, of the 172 peripherin/RDS mutation-and further refinement of genetic positioning of the peripherin/RDS gene. Am J Hum Genet 1998;62:192-195. [PubMed: 9443872]

Petrukhin K, Koisti MJ, Bakall B, Li W, Xie G, Marknell T, et al. Identification of the gene responsible for Best macular dystrophy. Nat Genet 1998;19:241-247. [PubMed: 9662395]

Piguet B, Heon E, Munier FL, Grounauer PA, Niemeyer G, Butler N, et al. Full characterization of the maculopathy associated with an Arg-172-Trp mutation in the RDS/peripherin gene. Ophthal Genet 1996; 17:175-186.

Poetsch A, Molday LL, Molday RS. The cGMP-gated channel and related glutamic acid-rich proteins interact with peripherin-2 at the rim region of rod photoreceptor disc membranes. J Biol Chem 2001;276:48009-48016. [PubMed: 11641407]

Poirier J, Baccichet A, Dea D, Gauthier S. Cholesterol synthesis and lipoprotein reuptake during synaptic remodelling in hippocampus in adult rats. Neuroscience 1993;55:81-90. [PubMed: 8350994]

Rakoczy PE, Baines M, Kennedy CJ, Constable IJ. Correlation between autofluorescent debris accumulation and the presence of partially processed forms of cathepsin D in cultured retinal pigment epithelial cells challenged with rod outer segments. Exp Eye Res 1996;63:159-167. [PubMed: 8983973] 
Rakoczy PE, Sarks SH, Daw N, Constable IJ. Distribution of cathepsin D in human eyes with or without age-related maculopathy. Exp Eye Res 1999;69:367-374. [PubMed: 10504270]

Rakoczy PE, Zhang D, Robertson T, Barnett NL, Papadimi-triou J, Constable IJ, Lai CM. Progressive age-related changes similar to age-related macular degeneration in a transgenic mouse model. Am J Pathol 2002;161:1515-1524. [PubMed: 12368224]

Rechtman E, Ciulla TA, Criswell MH, Pollack A, Harris A. An update on photodynamic therapy in agerelated macular degeneration. Expert Opin Pharmacother 2002;3:931-938. [PubMed: 12083992]

Rice DS, Tang Q, Williams RW, Harris BS, Davisson MT, Goldowitz D. Decreased retinal ganglion cell number and misdirected axon growth associated with fissure defects in Bst/+ mutant mice. Invest Ophthalmol Vis Sci 1997;38:2112-2124. [PubMed: 9331275]

Rivera A, White K, Stohr H, Steiner K, Hemmrich N, Grimm T, et al. A comprehensive survey of sequence variation in the ABCA4 (ABCR) gene in Stargardt disease and age-related macular degeneration. Am J Hum Genet 2000;67:800-813. [PubMed: 10958763]

Rohrer B, Goletz P, Znoiko S, Ablonczy Z, Ma JX, Redmond TM, Crouch RK. Correlation of regenerable opsin with rod ERG signal in Rpe653/3 mice during development and aging. Invest Ophthalmol Vis Sci 2003;44:310-315. [PubMed: 12506090]

Sato M, Abe T, Tamai M. Analysis of the metallothionein gene in age-related macular degeneration. Jpn J Ophthalmol 2000;44:115-121. [PubMed: 10715376]

Sauer CG, White K, Stohr H, Grimm T, Hutchinson A, Bernstein PS, et al. Evaluation of the G protein coupled receptor-75 (GPR75) in age related macular degeneration. Br J Ophthalmol 2001;85:969975. [PubMed: 11466257]

Schick JH, Iyengar SK, Klein BE, Klein R, Reading K, Liptak R, et al. A whole-genome screen of a quantitative trait of age-related maculopathy in sibships from the Beaver Dam Eye Study. Am J Ophthalmol 2003;136:970.

Schmidt S, Saunders AM, De La Paz MA, Postel EA, Heinis RM, Agarwal A, et al. Association of the apolipoprotein $\mathrm{E}$ gene with age-related macular degeneration: possible effect modification by family history, age, and gender. Mol Vis 2000;6:287-293. [PubMed: 11141572]

Schmidt S, Postel EA, Agarwal A, Allen IC Jr, Walters SN, De La Paz MA, et al. Detailed analysis of allelic variation in the ABCA4 gene in age-related maculopathy. Invest Ophthalmol Vis Sci 2003;44:2868-2875. [PubMed: 12824224]

Schultz DW, Klein ML, Humpert A, Majewski J, Schain M, Weleber RG, et al. Lack of an association of apolipoprotein E gene polymorphisms with familial age-related macular degeneration. Arch Ophthalmol 2003a;121:679-683. [PubMed: 12742846]

Schultz DW, Klein ML, Humpert AJ, Luzier CW, Persun V, Schain M, et al. Analysis of the ARMD1 locus: evidence that a mutation in HEMICENTIN-1 is associated with age-related macular degeneration in a large family. Hum Mol Genet 2003b;12:3315-3323. [PubMed: 14570714]

Seddon JM, Rosner B, Sperduto RD, Yannuzzi L, Haller JA, Blair NP, Willett W. Dietary fat and risk for advanced age-related macular degeneration. Arch Ophthalmol 2001;119:1191-1199. [PubMed: 11483088]

Seddon JM, Santangelo SL, Book K, Chong S, Cote J. A genomewide scan for age-related macular degeneration provides evidence for linkage to several chromosomal regions. Am J Hum Genet 2003;73:780-790. [PubMed: 12945014]

Shroyer NF, Lewis RA, Yatsenko AN, Wensel TG, Lupski JR. Cosegregation and functional analysis of mutant ABCR (ABCA4) alleles in families that manifest both Stargardt disease and age-related macular degeneration. Hum Mol Genet 2001;10:2671-2678. [PubMed: 11726554]

Sidman RL, Green MC. Retinal degeneration in the mouse: location of the rd locus in linkage group XVII. J Hered 1965;56:23-29. [PubMed: 14276177]

Silvestri G. Age-related macular degeneration: genetics and implications for detection and treatment. Mol Med Today 1997;3:84-91. [PubMed: 9060006]

Simonelli F, Margaglione M, Testa F, Cappucci G, Manitto MP, Brancato R, Rinaldi E. Apolipoprotein E polymorphisms in age-related macular degeneration in an Italian population. Ophthal Res 2001a; 33:325-328. 
Smith RS, John SW, Zabeleta A, Davisson MT, Hawes NL, Chang B. The bst locus on mouse chromosome 16 is associated with age-related subretinal neovascularization. Proc Natl Acad Sci USA 2000;97:2191-2195. [PubMed: 10681427]

Smith W, Assink J, Klein R, Mitchell P, Klaver CC, Klein BE, et al. Risk factors for age-related macular degeneration: pooled findings from three continents. Ophthalmology 2001;108:697-704. [PubMed: 11297486]

Snow KK, Seddon JM. Do age-related macular degeneration and cardiovascular disease share common antecedents? Ophthal Epidemiol 1999;6:125-143.

Soboleva G, Geis B, Schrewe H, Weber BH. Sorsby fundus dystrophy mutation Timp3(S156C) affects the morphological and biochemical phenotype but not metalloproteinase homeostasis. J Cell Physiol 2003;197:149-156. [PubMed: 12942551]

Souied EH, Benlian P, Amouyel P, Feingold J, Lagarde JP, Munnich A, et al. The epsilon4 allele of the apolipoprotein $\mathrm{E}$ gene as a potential protective factor for exudative age-related macular degeneration. Am J Ophthalmol 1998;125:353-359. [PubMed: 9512153]

Souied EH, Ducroq D, Rozet JM, Gerber S, Perrault I, Munnich A, et al. ABCR gene analysis in familial exudative age-related macular degeneration. Invest Ophthalmol Vis Sci 2000;41:244-247. [PubMed: 10634626]

Stone EM, Webster AR, Vandenburgh K, Streb LM, Hockey RR, Lotery AJ, Sheffield VC. Allelic variation in ABCR associated with Stargardt disease but not age-related macular degeneration. Nat Genet 1998;20:328-329. [PubMed: 9843201]

Stone EM, Lotery AJ, Munier FL, Heon E, Piguet B, Guymer RH, et al. A single EFEMP1 mutation associated with both Malattia leventinese and Doyne honeycomb retinal dystrophy. Nat Genet 1999;22:199-202. [PubMed: 10369267]

Tran H, Mattei M, Godyna S, Argraves WS. Human fibulin-1D: molecular cloning, expression and similarity with S1-5 protein, a new member of the fibulin gene family. Matrix Biol 1997;15:479493. [PubMed: 9106159]

Travis GH, Sutcliffe JG, Bok D. The retinal degeneration slow (rds) gene product is a photoreceptor disc membrane-associated glycoprotein. Neuron 1991;6:61-70. [PubMed: 1986774]

Tuo J, Muftuoglu M, Chen C, Jaruga P, Selzer RR, Brosh RM Jr, et al. The Cockayne Syndrome group $\mathrm{B}$ gene product is involved in general genome base excision repair of 8-hydroxyguanine in DNA. J Biol Chem 2001;276:45772-45779. [PubMed: 11581270]

Tuo J, Chen C, Zeng X, Christiansen M, Bohr VA. Functional crosstalk between hOgg1 and the helicase domain of Cockayne syndrome group B protein. DNA Repair Amst 2002a;1:913-927. [PubMed: 12531019]

Tuo J, Jaruga P, Rodriguez H, Dizdaroglu M, Bohr VA. The cockayne syndrome group B gene product is involved in cellular repair of 8-hydroxyadenine in DNA. J Biol Chem 2002b;277:30832-30837. [PubMed: 12060667]

Tuo J, Jaruga P, Rodriguez H, Bohr VA, Dizdaroglu M. Primary fibroblasts of Cockayne syndrome patients are defective in cellular repair of 8-hydroxyguanine and 8-hydroxyadenine resulting from oxidative stress. FASEB J 2003;17:668-674. [PubMed: 12665480]

Tuo, J.; Smith, B.; Chew, E.; Csaky, K.; Gery, I.; Chan, CC. The involvement of sequence variation and expression of CX3CR1 in the pathogenesis of age-related macular degeneration; Keystone Symposium, Human Genome Sequence Variation and the Inherited Basis of Common Disease, Poster 310; 2004.

van Nie R, Ivanyi D, Demant P. A new H-2-linked mutation, rds, causing retinal degeneration in the mouse. Tissue Antigens 1978;12:106-108. [PubMed: 705766]

Vogel BE, Hedgecock EM. Hemicentin, a conserved extracellular member of the immunoglobulin superfamily, organizes epithelial and other cell attachments into oriented line-shaped junctions. Development 2001;128:883-894. [PubMed: 11222143]

Weber BH, Vogt G, Pruett RC, Stohr H, Felbor U. Mutations in the tissue inhibitor of metalloproteinases-3 TIMP3 in patients with Sorsby's fundus dystrophy. Nat Genet 1994a;8:352-356. [PubMed: 7894485] 
Weber BH, Vogt G, Stohr H, Sander S, Walker D, Jones C. High-resolution meiotic and physical mapping of the best vitelliform macular dystrophy (VMD2) locus to pericentromeric chromosome 11. Am J Hum Genet 1994b;55:1182-1187. [PubMed: 7977378]

Weber BH, Lin B, White K, Kohler K, Soboleva G, Herterich S, et al. A mouse model for Sorsby fundus dystrophy. Invest Ophthalmol Vis Sci 2002;43:2732-2740. [PubMed: 12147610]

Webster AR, Heon E, Lotery AJ, Vandenburgh K, Casavant TL, Oh KT, et al. An analysis of allelic variation in the ABCA4 gene. Invest Ophthalmol Vis Sci 2001;42:1179-1189. [PubMed: 11328725]

Weeks DE, Conley YP, Tsai HJ, Mah TS, Rosenfeld PJ, Paul TO, et al. Age-related maculopathy: an expanded genome-wide scan with evidence of susceptibility loci within the 1q31 and 17q25 regions. Am J Ophthalmol 2001;132:682-692. [PubMed: 11704029]

Wells J, Wroblewski J, Keen J, Inglehearn C, Jubb C, Eckstein A, et al. Mutations in the human retinal degeneration slow (RDS) gene can cause either retinitis pigmentosa or macular dystrophy. Nat Genet 1993;3:213-218. [PubMed: 8485576]

Weng J, Mata NL, Azarian SM, Tzekov RT, Birch DG, Travis GH. Insights into the function of Rim protein in photoreceptors and etiology of Stargardt's disease from the phenotype in abcr knockout mice. Cell 1999;98:13-23. [PubMed: 10412977]

Wenzel A, Grimm C, Samardzija M, Reme CE. The genetic modifier Rpe65Leu(450): effect on light damage susceptibility in c-Fos-deficient mice. Invest Ophthalmol Vis Sci 2003;44:2798-2802. [PubMed: 12766089]

White K, Marquardt A, Weber BH. VMD2 mutations in vitelliform macular dystrophy (Best disease) and other maculopathies. Hum Mutat 2000;15:301-308. [PubMed: 10737974]

Yanagihashi S, Nakazawa M, Kurotaki J, Sato M, Miyagawa Y, Ohguro H. Autosomal dominant central areolar choroidal dystrophy and a novel Arg195Leu mutation in the peripherin/RDS gene. Arch Ophthalmol 2003;121:1458-1461. [PubMed: 14557183]

Yoshida A, Yoshida M, Yoshida S, Shiose S, Hiroishi G, Ishibashi T. Familial cases with age-related macular degeneration. Jpn J Ophthalmol 2000;44:290-295. [PubMed: 10913649]

Zhang K, Kniazeva M, Hutchinson A, Han M, Dean M, Allikmets R. The ABCR gene in recessive and dominant Stargardt diseases: a genetic pathway in macular degeneration. Genomics 1999;60:234237. [PubMed: 10486215]

Zhang K, Kniazeva M, Han M, Li W, Yu Z, Yang Z, et al. A 5-bp deletion in ELOVL4 is associated with two related forms of autosomal dominant macular dystrophy. Nat Genet 2001;27:89-93. [PubMed: 11138005] 


\section{Table 1}

AMD-related chromosomal loci with lod $\geq 2$

\begin{tabular}{llll}
\hline AMD locus & Marker & Maximum lod & References \\
\hline $1 \mathrm{q} 25-31$ & D1S240/D1S412 & 3.20 & $\begin{array}{l}\text { Klein et al. (1998),Majewski et al. (2003),Seddon et al. } \\
\text { (2003), Weeks et al. (2001),Iyengar et al. (2004) }\end{array}$ \\
2q31/2q32 & D2S1391/D2S1384 & $2.32 / 2.03 a a$ & Seddon et al. (2003) \\
3p13 & D12S1300/D12S1763 & 2.19 & Majewski et al. (2003),Schick et al. (2003) \\
6q14 & D6S1056/D6S249 & $3.59 / 3.17$ & Kniazeva et al. (2000) \\
9q33 & D9S934/D9S934 & 2.06 & Majewski et al. (2003) \\
$10 q 26$ & D10S1230 & 3.06 & (2004) \\
& & Weeks et al. (2001) \\
17q25 & D17S928 & 3.16 & Seddon et al. (2003) \\
22q12 & D22S1045 & 2.0 & \\
\hline
\end{tabular}

${ }^{a}$ Non-parametric $\mathrm{Z}$ score calculated by Genehunter software and is considered as extremely conservative (Seddon et al., 2003).

$b_{\text {Highly associated with } 10 \mathrm{q} 26 .}$ 
Table 2

Causative genes of other retinal and macular dystrophies and their relationship with AMD

\begin{tabular}{|c|c|c|c|c|}
\hline Gene & Locus & Implicated diseases & AMD-association findings & Studies \\
\hline$V M D 2$ & $11 \mathrm{q} 13$ & Best disease & No significant association & $\begin{array}{l}\text { White et al. (2000),Allikmets } \\
\text { et al. (1999),Kramer et al. } \\
\text { (2000),Lotery et al. (2000) }\end{array}$ \\
\hline EFEMP1 & $2 \mathrm{p} 16$ & $\begin{array}{l}\text { Malattia leventinese and } \\
\text { Doyne Honeycomb Retinal } \\
\text { Dystrophy }\end{array}$ & No changes found & $\begin{array}{l}\text { Li et al., (2001),Zhang et al. } \\
\text { (2001) }\end{array}$ \\
\hline GPR75 & $2 \mathrm{p} 16$ & & $\begin{array}{l}\text { No statistical evidence for an } \\
\text { association between the variants and } \\
\text { AMD }\end{array}$ & Sauer et al. (2001) \\
\hline TIMP3 & $\begin{array}{l}22 \mathrm{q} 12.1- \\
\mathrm{q} 13.2\end{array}$ & Sorsby Fundus Dystrophy & $\begin{array}{l}\text { No evidence of sequence variation in } \\
\text { AMD patients. Confirmed by } \\
\text { linkage studies }\end{array}$ & Felbor et al. (1997) \\
\hline $\begin{array}{l}\text { Peripherin- } \\
R D S\end{array}$ & $6 \mathrm{p} 21$ & $\begin{array}{l}\text { Pattern Dystrophies, } \\
\text { progressive macular } \\
\text { degeneration, dominant } \\
\text { retinitis pigmentosa (RP), } \\
\text { digenic RP }\end{array}$ & $\begin{array}{l}\text { No association found. } \\
\text { Polymorphisms are equally common } \\
\text { in both AMD case and matched } \\
\text { control populations }\end{array}$ & $\begin{array}{l}\text { Silvestri (1997),Keen and } \\
\text { Inglehearn (1996) }\end{array}$ \\
\hline $\begin{array}{l}A B C A 4 \\
(A B C R)\end{array}$ & $1 \mathrm{p} 21-\mathrm{p} 22$ & Stargadt-like disease & $\begin{array}{l}\text { Significant association established } \\
\text { between ABCR variants (in } \\
\text { particular, D1277N and G1961E) } \\
\text { and AMD risk in matched control } \\
\text { meta-analyses and cohort studies }\end{array}$ & $\begin{array}{l}\text { Souied et al., (2000),Stone et } \\
\text { al. (1998),Guymer et al. } \\
\text { (2001),Klaver et al. } \\
\text { (1998a),Michaelides et al. } \\
\text { (2003),Rivera et al. } \\
\text { (2000),Schmidt et al., } \\
\text { 2003,Webster et al. (2001) } \\
\text { Allikmets et al., } \\
\text { (1997a),Allikmets } \\
\text { (2000),Mata et al. } \\
\text { (2001),Shroyer et al. } \\
\text { (2001),Zhang et al. (1999) }\end{array}$ \\
\hline ELOVLA & 6q14 & Dominant Stargardt disease & $\begin{array}{l}\text { No statistically significant difference } \\
\text { in } E L O V L 4 \text { variant allele frequencies } \\
\text { between AMD patients and age- } \\
\text { matched controls }\end{array}$ & Ayyagari et al. (2001) \\
\hline
\end{tabular}


Oxidative stress associated SNPs and AMD

\section{Table 3}

\begin{tabular}{|c|c|c|c|}
\hline Gene and SNP & Locus & AMD-association findings & Studies \\
\hline Cytochrome P-450 1A1 & $15 q 22-q 24$ & No association found in Japanese population & Kimura et al. (2000) \\
\hline $\begin{array}{l}\text { Microsomal epoxide hydrolase } \\
\text { exon-4 (MEHE-4) }\end{array}$ & $1 \mathrm{q} 42.1$ & No association found in Japanese population & Kimura et al. (2000) \\
\hline Glutathione S-transferase theta1 & $22 q 11.23$ & No association found in Japanese population & Kimura et al. (2000) \\
\hline Glutathione S-transferase mu 1 & $1 \mathrm{p} 13.3$ & No association found in Japanese population & Kimura et al. (2000) \\
\hline $\begin{array}{l}\text { SOD2, manganese superoxide } \\
\text { dismustase (MnSOD) isoform }\end{array}$ & $6 \mathrm{q} 25$ & $\begin{array}{l}\text { Significant association of MnSOD with AMD ( } p \\
=0.0005 \text { after Bonferroni correction). Increased } \\
\text { frequency of alanine allele and alanine/alanine } \\
\text { genotype }\end{array}$ & Kimura et al. (2000) \\
\hline $\begin{array}{l}\text { Microsomal epoxide hydrolase } \\
\text { exon-3 (MEHE-3) }\end{array}$ & $1 \mathrm{q} 42.1$ & $\begin{array}{l}\text { Weak association (odds ratio } 2.2, p=0.02 \text { after } \\
\text { Bonfererroni correction) }\end{array}$ & Kimura et al. (2000) \\
\hline Paraoxonase & $7 q 21.3$ & $\begin{array}{l}\text { Association found between both GlnArg } 192 \text { and } \\
\text { Leu54Met polymorphisms and AMD in Japanese } \\
\text { populations ( } 192 p=0.0445 ; 54 p=0.0323)\end{array}$ & Ikeda et al. (2001) \\
\hline Metallothionein & $16 \mathrm{q} 13$ & No association found & Sato et al. (2000) \\
\hline
\end{tabular}


Protective SNPs against AMD

Table 4

\begin{tabular}{|c|c|c|c|}
\hline Gene & Locus & AMD-association findings & Studies \\
\hline \multirow[t]{4}{*}{$\begin{array}{l}\text { Apolipoprotein E } \\
\text { (ApoE) E2, E3, E4 }\end{array}$} & \multirow[t]{4}{*}{$19 q 13.2$} & $\begin{array}{l}\text { The frequency of the E4 allele carriers was significantly higher in the general } \\
\text { population than in AMD patients }(p=0.002) \text {. The frequency of the E } 2 \text { allele } \\
\text { was higher in the patients }(p=0.069)\end{array}$ & $\begin{array}{l}\text { Simonelli et al. } \\
\text { (2001a) }\end{array}$ \\
\hline & & $\begin{array}{l}\text { No significant association found. Trend for a decreased risk of AMD } \\
\text { associated with APOE4 observed in unrelated patients with a family history } \\
\text { of AMD }\end{array}$ & $\begin{array}{l}\text { Schultz et al. } \\
\text { (2003a) }\end{array}$ \\
\hline & & $\begin{array}{l}\text { Significant association of E4 allele with decreased risk of AMD (odds ratio } \\
0.43 \text { ). E2 allele associated with slightly increased risk for AMD (odds ratio } \\
\text { 1.5) }\end{array}$ & $\begin{array}{l}\text { Klaver et al. } \\
(1998 b)\end{array}$ \\
\hline & & $\begin{array}{l}\text { Lower frequency of E4 allele carriers observedin exudative } \operatorname{AMD}(p \\
<0.0009) \text { less frequent in AMD group with control subjects }(p<0.006)\end{array}$ & Souied et al.(1998) \\
\hline $\begin{array}{l}\text { Angiostensin- } \\
\text { converting enzyme } \\
(\text { ACE), Alu+/+ insert }\end{array}$ & $17 \mathrm{q} 23$ & $\begin{array}{l}\text { No significant difference observed between the controls and AMD } \\
\text { populations of allelic and genotypic frequencies. However, the Alu+/+ } \\
\text { genotype occurred } 4.5 \text { times more frequently in the control population than } \\
\text { the dry/atrophic AMD population }\end{array}$ & Hamdi et al. (2002) \\
\hline
\end{tabular}

